\title{
Increased ROS Scavenging and Antioxidant Efficiency of Chlorogenic Acid Compound Delivered via a Chitosan Nanoparticulate System for Efficient In Vitro Visualization and Accumulation in Human Renal Adenocarcinoma Cells
}

\author{
Revathi Kavi Rajan ${ }^{1,2} ®$, Mohd Zobir Hussein ${ }^{3} \oplus$, Sharida Fakurazi ${ }^{4}$, Khatijah Yusoff ${ }^{5}$ and \\ Mas Jaffri Masarudin 1,2,3,*(D) \\ 1 Department of Cell and Molecular Biology, Faculty of Biotechnology and Biomolecular Sciences, \\ University Putra Malaysia, 43400 Serdang, Selangor, Malaysia \\ 2 Cancer Research Laboratory Institute of Biosciences, University Putra Malaysia, 43400 Serdang, \\ Selangor, Malaysia \\ 3 Materials Synthesis and Characterization Laboratory, Institute of Advanced Technology, University Putra \\ Malaysia, 43400 Serdang, Selangor, Malaysia \\ 4 Department of Human Anatomy, Faculty of Medicine and Health Sciences, University Putra Malaysia, \\ 43400 Serdang, Selangor, Malaysia \\ 5 Department of Microbiology, Faculty of Biotechnology and Biomolecular Sciences, University Putra \\ Malaysia, 43400 Serdang, Selangor, Malaysia \\ * Correspondence: masjaffri@upm.edu.my; Tel.: +603-8947-1970
}

Received: 11 August 2019; Accepted: 25 August 2019; Published: 20 September 2019

\begin{abstract}
Naturally existing Chlorogenic acid (CGA) is an antioxidant-rich compound reported to act a chemopreventive agent by scavenging free radicals and suppressing cancer-causing mechanisms. Conversely, the compound's poor thermal and $\mathrm{pH}$ (neutral and basic) stability, poor solubility, and low cellular permeability have been a huge hindrance for it to exhibit its efficacy as a nutraceutical compound. Supposedly, encapsulation of CGA in chitosan nanoparticles (CNP), nano-sized colloidal delivery vector, could possibly assist in enhancing its antioxidant properties, in vitro cellular accumulation, and increase chemopreventive efficacy at a lower concentration. Hence, in this study, a stable, monodispersed, non-toxic CNP synthesized via ionic gelation method at an optimum parameter $(600 \mu \mathrm{L}$ of $0.5 \mathrm{mg} / \mathrm{mL}$ of chitosan and $200 \mu \mathrm{L}$ of $0.7 \mathrm{mg} / \mathrm{mL}$ of tripolyphosphate), denoted as $\mathrm{CNP}^{\circ}$, was used to encapsulate CGA. Sequence of physicochemical analyses and morphological studies were performed to discern the successful formation of the CNP ${ }^{\circ}$-CGA hybrid. Antioxidant property (studied via DPPH (1,1-diphenyl-2-picrylhydrazyl) assay), in vitro antiproliferative activity of $\mathrm{CNP}^{\circ}$-CGA, and in vitro accumulation of fluorescently labeled (FITC) $\mathrm{CNP}^{\circ}$-CGA in cancer cells were evaluated. Findings revealed that successful formation of $\mathrm{CNP}^{\circ}$-CGA hybrid was reveled through an increase in particle size $134.44 \pm 18.29 \mathrm{~nm}$ (polydispersity index (PDI) $0.29 \pm 0.03$ ) as compared to empty $\mathrm{CNP}^{\circ}, 80.89 \pm 5.16 \mathrm{~nm}$ (PDI $0.26 \pm 0.01$ ) with a maximal of $12.04 \mu \mathrm{M}$ CGA loaded per unit weight of $\mathrm{CNP}^{\circ}$ using $20 \mu \mathrm{M}$ of CGA. This result correlated with Fourier-Transform Infrared (FTIR) spectroscopic analysis, transmission Electron Microscopy (TEM) and field emission scanning (FESEM) electron microscopy, and ImageJ evaluation. The scavenging activity of $\mathrm{CNP}^{\circ}$-CGA $\left(\mathrm{IC}_{50} 5.2\right.$ $\pm 0.10 \mu \mathrm{M})$ were conserved and slightly higher than $\mathrm{CNP}^{\circ}\left(\mathrm{IC}_{50} 6.4 \pm 0.78 \mu \mathrm{M}\right)$. An enhanced cellular accumulation of fluorescently labeled $\mathrm{CNP}^{\circ}$-CGA in the human renal cancer cells (786-O) as early as $30 \mathrm{~min}$ and increased time-dependently were observed through fluorescent microscopic visualization and flow cytometric assessment. A significant concentration-dependent antiproliferation activity of encapsulated CGA was achieved at $\mathrm{IC}_{50}$ of $16.20 \mu \mathrm{M}$ as compared to CGA itself (unable to determine from the cell proliferative assay), implying that the competent delivery vector, chitosan nanoparticle,
\end{abstract}


is able to enhance the intracellular accumulation, antiproliferative activity, and antioxidant properties of CGA at lower concentration as compared to CGA alone.

Keywords: chitosan nanoparticles; chlorogenic acid; chemopreventive; nanobiotechnology; drug encapsulated chitosan nanoparticles; in vitro accumulation of encapsulated chlorogenic acid; 1,1-Diphenyl-2-picrylhydrazine assay; MTT assay

\section{Introduction}

The history of therapeutic compounds discovery from various sources (i.e., natural, semi-synthetic, and synthetic) can be traced back to the 1800s. One such compound include the naturally produced 5-O-caffeoylquinic acid (5-CQA) compound or commonly known as chlorogenic acid (CGA); an ester of caffeic acid and L-quinic acid [1,2]. This phytochemical is one of the active compounds utilized in Chinese traditional herbal medication plant, Lonicera japonica Thunb. [3]. The compound can be lavishly extracted from coffee beans, tea, vegetables (potato, artichoke, tomatoes, eggplants), fruits (berries, apples, prunes, kiwi), and herbaceous plants (Artemisia capillaris, Ilex paraguariensis, Pimpinella anisum, Cymbopogon citratus) [4-8].

CGA is an extensively studied plant secondary metabolite with potent antioxidant strength and other conceivable therapeutic properties. The presence of a catechol structure serves as the primary binding site for free radicals $[9,10]$. CGA is able to chelate metal ions, inhibit lipid oxidation, and scavenge free radicals, oxygen and nitrogen species (superoxides, hydroxyl, peroxy, peroxynitrate and hypochlorous acid) [2,10-13]. Lu et al. (2000) observed that CGA had enhanced scavenging effects compared to Vitamin C and E; with two to three-fold DPPH radicals scavenging effects and 10 to 30-folds superoxide anion radical scavenging effects [14].

Therewithal, studies have also shown potential participation of CGA as a nutraceutical compound in both in vitro and in vivo applications; which includes prevention against microorganisms [15-17], and potentially lowered the risk of certain health conditions such as obesity [18], cancer [19], hypertension [20], diabetic [21], myocardial infarction [22], and so on. However, regardless of ongoing studies on therapeutic properties of CGA, there are other impediment factors decelerating its pharmacological effects.

The compound integrity of CGA is influenced by temperature and pH. CGA was reported to undergo isomerization or possibly other chemical reactions (esterification, hydrolysis, etc.) under the exposure of high temperature (time-dependent), and at basic and neutral $\mathrm{pH}$ [23-27]. This, in return, affects the synthesis process and its nutraceutical trait. This polyphenol was also reported to exhibit poor cellular permeability [2,28-30]. Olthof et al. (2001) and Gonthier et al. (2003) perceived that only about $33 \%$ of ingested CGA was efficiently absorbed into the small intestines; the remainder are lost along the gastrointestinal tract or decomposed by microflora in the cecum [28,29]. Likewise, Farah et al. (2008) also reported similar findings; only $30 \%$ of CGA was absorbed into blood circulation; inferring the bioavailability and efficacy of CGA are affected in this circumstance, in spite of its therapeutic potential [1]. Besides, CGA also appeared to show non-toxic attribute in in vitro condition [31].

Hence to confront these limitations, administration of a high dosage was used [1] but in which led to observable events of severe side effects such as DNA damage [32], cardiovascular complications [33], inflammatory and oxidative stress injuries [34], disruption in natural oxidant and antioxidant balance mechanisms [34], as well as vomiting, asthma, pruritus, anxiety, diarrhea, liver damage and kidney injury [34,35]. Additionally, the lack of knowledge of CGA therapeutic mechanisms also halts research that ventures further into its pharmacological functions [36].

Alternatively, nanoparticles incorporated drug delivery systems (nano-DDS) have been proposed as an auxiliary avenue to deliver CGA to the targeted sites in controlled released mechanism with conserved antioxidant and therapeutic strength, minimized administration dosage, and lowered side 
effects [8,31,37-39]. This study employs one of the most commonly adapted nanomaterials in nano-DDS, chitosan nanoparticles (CNP); synthesized via ionic gelation between protonated amine groups, $-\mathrm{NH}_{3}{ }^{+}$ of chitosan (CS) and anionic phosphate groups, $-\mathrm{PO}_{4}{ }^{3-}$ of cross-linker tripolyphosphate (TPP) [40,41]. Due to its biocompatible, biodegradable, and simple and mild synthesis process, CNP has been widely opted for in pharmaceutical industries as a safe vector to deliver therapeutic drug compounds, genes, proteins, peptides, DNA, RNA, vaccines, antigens, and different types of bio-payloads [42-44].

Collectively, this vector is able to protect the cargo from degradation by phagocytosis and circumvent drug resistance mechanisms, deliver therapeutic drugs to the targeted sites, provide an alternative route for insoluble drugs to permeate cells, improve the bioavailability and therapeutic efficacy of drugs in the living system, upturn the enhanced permeability and retention (EPR) effect, participate in sustained released rates of the drugs, and conserve the pharmacodynamics effects and in vivo stability of drugs [40,45-49]. Vila et al. (2004)—concerning the nasal administration of tetanus toxoid encapsulated CNP in mice model—showed a prominent high stimulation and enduring humoral immune response compared to tetanus toxoid vaccine alone [50].

This study was outlined based on the objective of enhancing the in vitro accumulation and cytotoxicity effect on human kidney cancer cell line (786-O), and improvise the antioxidant activity of chlorogenic acid by encapsulating into fabricated stable, monodispersed, colloidal CNP as a delivery vector. The physicochemical characterizations, antioxidant strength, and in vitro cytotoxicity activities of CGA and CNP encapsulated CGA hybrid were analyzed and optimized for better intracellular efficacy of CGA. Additionally, the in vitro accumulation of CGA was studied using fluorescently labeled CNP $(f C N P)$. Hence, validating the encapsulated CGA has high potential as a drug delivery vector in pharmaceutical applications.

\section{Results}

\subsection{Characterization of Synthesized CNP and Determination of Optimal Parameters}

CNP were formulated using three parameters as described in Table 1. The influence of TPP volume on the percentage of utilized primary amine groups $\left(-\mathrm{NH}_{3}{ }^{+}\right)$, particle size distributions, and the stability of the nanoparticles depicted in Figures 1 and 2. Following addition of a small volume of $1-3 \%$ of acetic acid, the primary amine groups $\left(-\mathrm{NH}_{2}\right)$ of $\mathrm{CS}$ were protonated [51] spontaneously cross-linking with multivalent anionic phosphate groups $\left(-\mathrm{PO}_{4}{ }^{3-}\right)$ of TPP to form hydrophilic CNP. However, not all $-\mathrm{NH}_{3}{ }^{+}$groups participated in the cross-linking reaction. Shown in Figure 1, TNBS assay detected unutilized $-\mathrm{NH}_{3}{ }^{+}$groups and subsequently confirms the formation of nanoparticles. On an overall basis, the percentage of utilized $-\mathrm{NH}_{3}{ }^{+}$in formation of nanoparticles increased with the TPP volumes.

Table 1. Chitosan nanoparticles (CNP) synthesis based on three different formulations; CNP-F1, CNP-F2, and CNP-F3. Prior to formation of CNP, CS and TPP solutions were diluted to different concentrations and adjusted to $\mathrm{pH} 5$ and $\mathrm{pH}$ 2, respectively. CNP were synthesized through ionic gelation interactions between a fixed volume of CS, $600 \mu \mathrm{L}$ and different volumes of TPP.

\begin{tabular}{ccccc}
\hline Formulations & Solution & $\begin{array}{c}\text { Concentration } \\
(\mathbf{m g} / \mathbf{m L})\end{array}$ & pH & Volume $(\mu \mathrm{L})$ \\
\hline \multirow{2}{*}{ CNP-F1 } & CS & 0.50 & 5 & 600 \\
& TPP & 0.70 & 2 & $20,50,100,150,200,250,300$ \\
\hline \multirow{2}{*}{ CNP-F2 } & CS & 0.25 & 5 & 600 \\
& TPP & 0.35 & 2 & $20,50,100,150,200,250,300$ \\
\hline \multirow{2}{*}{ CNP-F3 } & CS & 0.10 & 5 & 600 \\
& TPP & 0.20 & 2 & $20,50,100,150,200,250,300$ \\
\hline
\end{tabular}




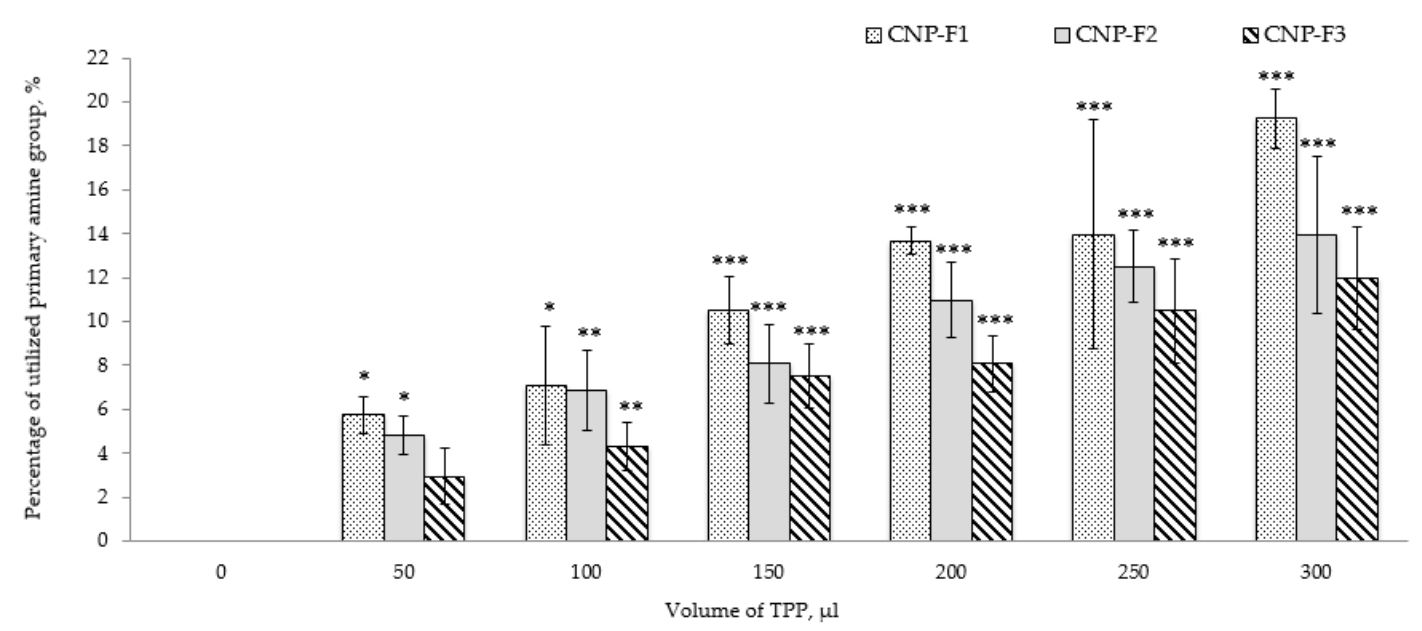

Figure 1. Influence of TPP volume on percentage of utilized amine group in combined graph bar CNP-F1, CNP-F2, and CNP-F3. The percentage of utilized primary amine $\left(-\mathrm{NH}_{3}{ }^{+}\right)$groups increases with TPP addition. The figure suggests that with increasing TPP volume, more phosphate ions, $-\mathrm{PO}_{4}{ }^{3-}$ groups were available to readily interact with $-\mathrm{NH}_{3}{ }^{+}$groups to form $\mathrm{CNP}$, hence reducing the availability of free $-\mathrm{NH}_{3}{ }^{+}$groups. Error bars represent the standard deviation (SD) of three independent replicates of the experiment. * shows degree of significant difference, $p<0.0001$ compared to control, $0 \mu \mathrm{L}$ of TPP volume.

The percentage of utilized $-\mathrm{NH}_{3}{ }^{+}$graph showed an increase of $13.50 \%$ utilized $-\mathrm{NH}_{3}{ }^{+}$(from $5.75 \pm 0.82 \%$ to $19.25 \pm 1.36 \%$ ) as the TPP volume increased from $50 \mu \mathrm{L}$ to $300 \mu \mathrm{L}$ in CNP-F1. Likewise, the utilized $-\mathrm{NH}_{3}{ }^{+}$percentage in CNP-F2 and CNP-F3 increased $9.12 \%$ (from $4.83 \pm 0.89 \%$ to $13.95 \pm 3.60 \%$ ) and $9.01 \%$ (from $2.96 \pm 1.29 \%$ to $11.97 \pm 2.34 \%$ ), respectively, suggesting that at lower volumes of TPP, lesser $-\mathrm{PO}_{4}{ }^{3-}$ groups were available to cross-link with $-\mathrm{NH}_{3}{ }^{+}$; however, this circumstance overturned as the TPP volume increased. More $-\mathrm{PO}_{4}{ }^{3-}$ groups were present to interact with $-\mathrm{NH}_{3}{ }^{+}$groups to form $\mathrm{CNP}$, hence increasing the percentage of utilized $-\mathrm{NH}_{3}{ }^{+}$. A similar corresponding trend was also perceived previously by Masarudin et al. (2015) and this data correlated with particle size and dispersity of synthesized CNP as observed in Dynamic Light Scattering (DLS) analysis [52].

Based on Figure 1, a general decrease was observed in average CNP sizes (diameter in $\mathrm{nm}, \mathrm{nm}$ ) and PDI values as the volume of TPP increased for all three formulations. At lower TPP volumes, high variable particle size and PDI value data were observed across the three parameters due to insufficient availability of $-\mathrm{PO}_{4}{ }^{3-}$ to cross-link with $-\mathrm{NH}_{3}{ }^{+}$. However, the particle size and PDI value lessened as the TPP volume was increased as more $-\mathrm{PO}_{4}{ }^{3-}$ became available to perform internal cross-linking with $-\mathrm{NH}_{3}{ }^{+}$within the $\mathrm{CS}$ particles, thus forming a more compact $\mathrm{CNP}$ and lower agglomeration rate. These results further supported the TNBS analysis.

Synthesis of nanoparticle sized between $50 \mathrm{~nm}$ to $100 \mathrm{~nm}$, a range volume of $200 \mu \mathrm{L}$ to $250 \mu \mathrm{L}$ TPP for CNP-F1 (Figure 2A), $150 \mu \mathrm{L}$ to $250 \mu \mathrm{L}$ TPP for CNP-F2 (Figure 2B), and $250 \mu \mathrm{L}$ of TPP for CNP-F3 (Figure 2C) were needed. CNP with particle size ranged between 50 and $100 \mathrm{~nm}$ were favored because at these size ranges, nanoparticles were able encapsulate more drugs, showed better cellular permeability across tight junctions and cell membranes, and gave extended in vivo circulation half-life [42,52-55]. PDI value represents the stability and dispersity of nanoparticle sizes; lower PDI (less than 0.3 ) which indicates stable and monodispersed nanoparticles was preferred compared to higher PDI (more than 0.7) which shows unstable and uneven distribution of particle sizes or agglomeration [56]. Based on Figure 2, the preferred PDI values was only observed in $200 \mu \mathrm{L}$ TPP for CNP-F1 (Figure 2A), and at $300 \mu \mathrm{L}$ TPP for CNP-F2 (Figure 2B) and CNP-F3 (Figure 2C). 


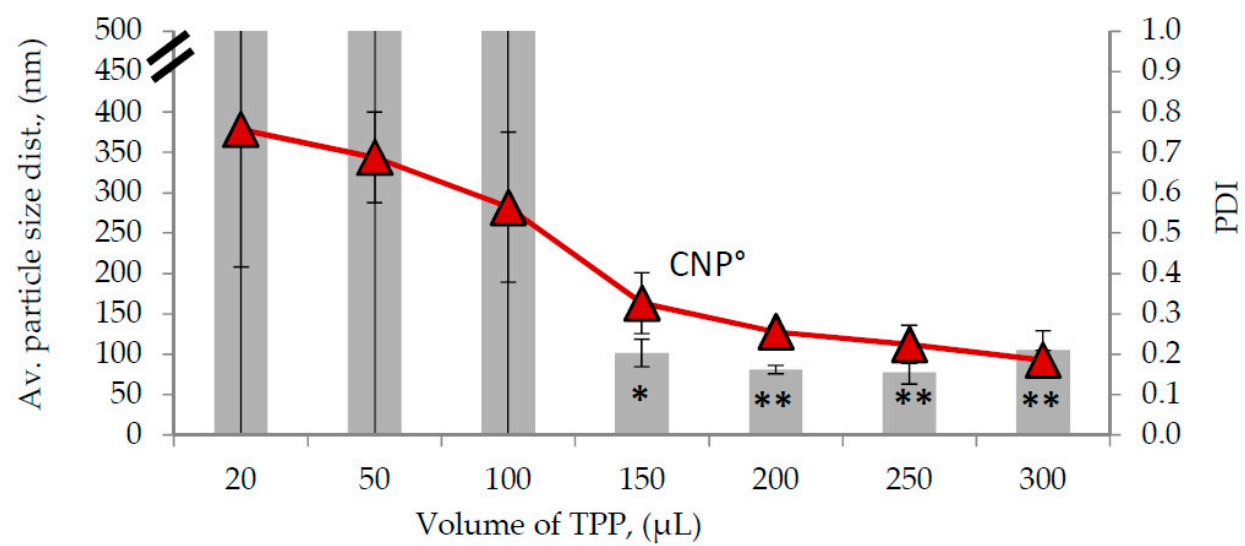

(A)

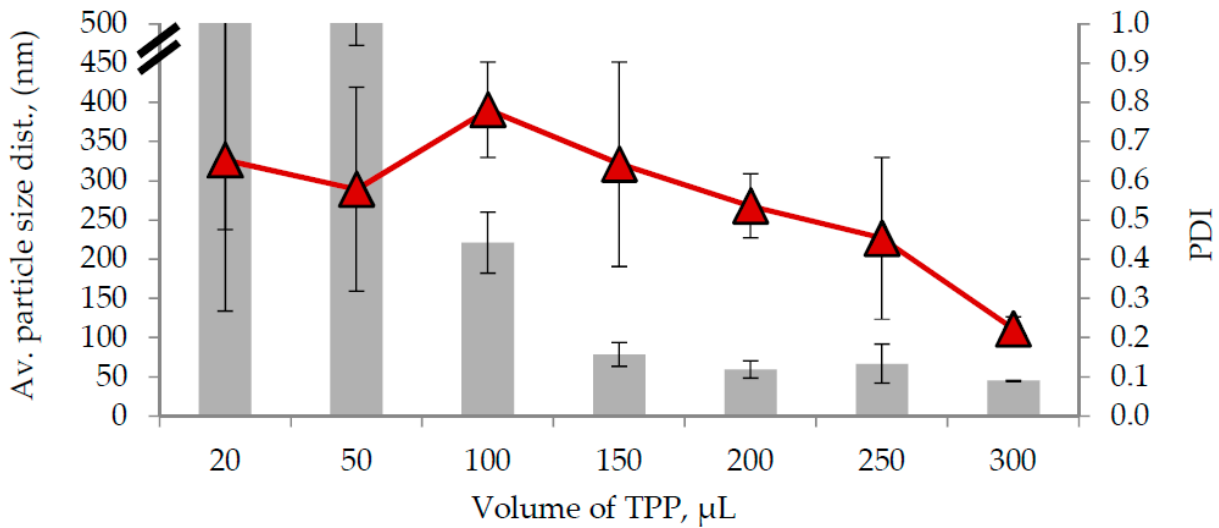

(B)

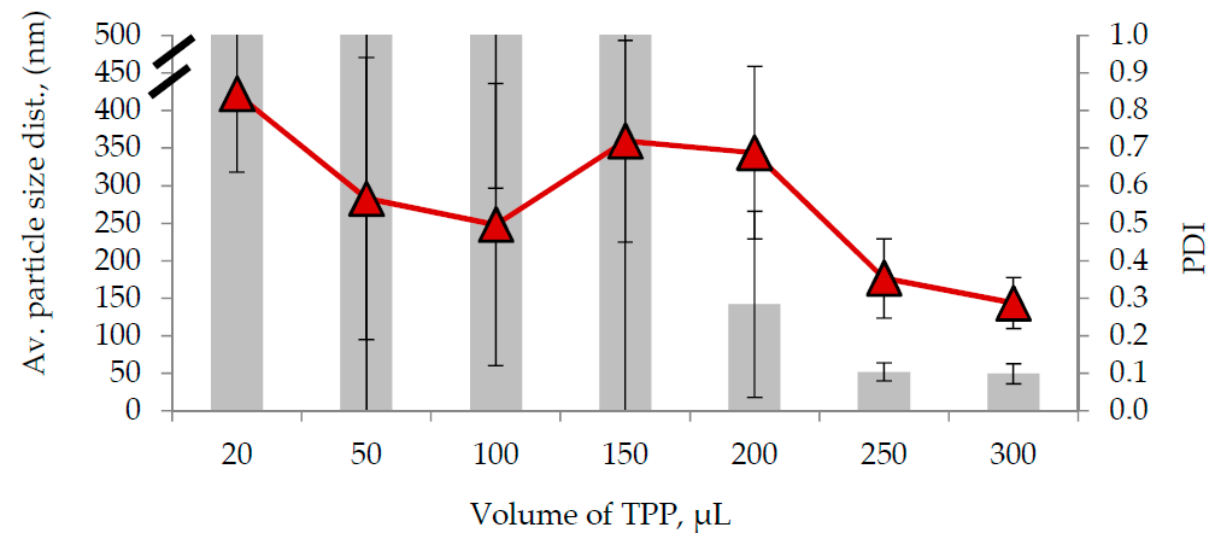

(C)

Figure 2. The influence of TPP volume of (A) CNP-F1, (B) CNP-F2, and (C) CNP-F3 on average particle size distribution (diameter in $\mathrm{nm}, \mathrm{nm}$ ), and polydispersity index (PDI). The average particle size distribution was illustrated in graph bar and PDI was illustrated in line graph. $\mathrm{CNP}^{\circ}$ represents the optimal parameter required to synthesize stable and evenly distributed nanoparticle sizes. Error bars represent the SD of three independent replicates of the experiment. * shows degree of significant difference, $p<0.0015$ compared to $20 \mu \mathrm{L}$ of TPP volume.

Collectively, formation of stable and monodispersed CNP within the size range of 50-100 nm, was only be attained from two CS: TPP volume ratios of 3:1 and 2.4:1 of CNP-F1. CNP-F1 at 3:1 CS: TPP volume ratio parameter yield an average CNP particle size distribution of $80.89 \pm 5.16 \mathrm{~nm}$ and a PDI value of $0.26 \pm 0.01$, while at 2.4:1 CS: TPP volume ratio produced a CNP of $77.36 \pm 13.99 \mathrm{~nm}$ and $0.22 \pm 0.05$ PDI value. A consistency in small-sized, stable, monodispersed CNP with a low PDI 
value was perceived from using $200 \mu \mathrm{L}$ TPP and $600 \mu \mathrm{L}$ CS in CNP-F1(Figure 3) and was subsequently chosen as the optimum parameter to form $\mathrm{CNP}$ (denoted as $\mathrm{CNP}^{\circ}$ in subsequent sections).

$\begin{array}{rlllll} & & & \text { Diam. (nm) } & \% \text { Intensity } & \text { Width (nm) } \\ \text { Z-Average (d.nm): } & 79.34 & \text { Peak 1: } & 109.1 & 100.0 & 63.48 \\ \text { Pdl: } & 0.248 & \text { Peak 2: } & 0.000 & 0.0 & 0.000 \\ \text { Intercept: } & 0.937 & \text { Peak 3: } & 0.000 & 0.0 & 0.000\end{array}$

Result quality : Good
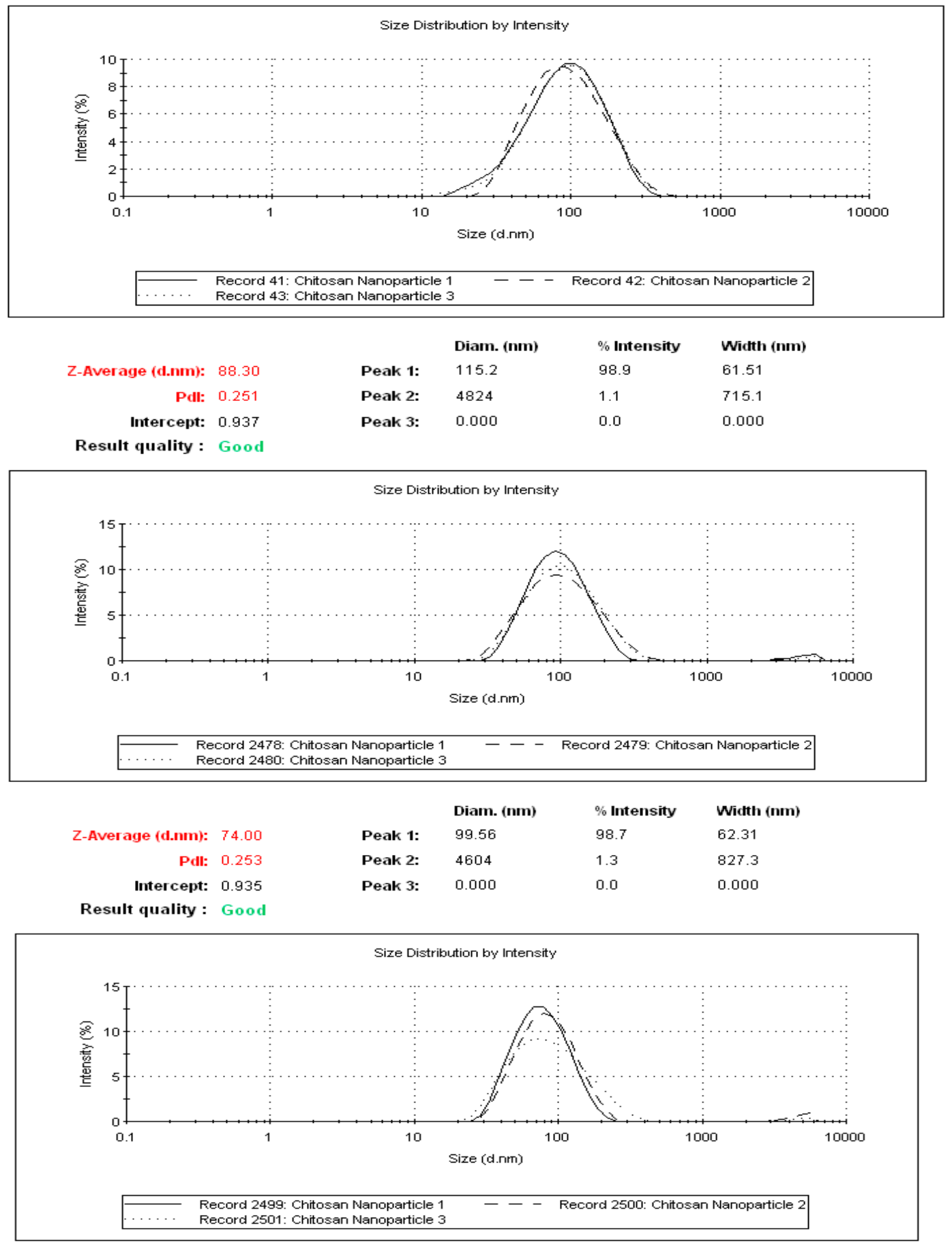

Figure 3. Reproducibility of DLS analyses for the optimal parameter, $\mathrm{CNP}^{\circ}$ using $600 \mu \mathrm{L}$ CS $(0.5 \mathrm{mg} / \mathrm{mL})$ and $200 \mu \mathrm{L}$ TPP $(0.7 \mathrm{mg} / \mathrm{mL})$. Consistency in synthesizing nanoparticle with average $80.89 \pm 5.16 \mathrm{~nm}$ with PDI value of $0.26 \pm 0.01$ were observed in all three replicates; showing that at this parameter, stable and monodispersed $\mathrm{CNP}^{\circ}$ were consistently able to be synthesized. 
In this study, CS concentration below $1.5 \mathrm{mg} / \mathrm{mL}$ and TPP below $1.0 \mathrm{mg} / \mathrm{mL}$ was used as better CS solubility and CNP stability was attained [57]. Similarly, CS at pH 5 and TPP at pH 2 were opted as previously described by Masarudin et al. (2015) [52]. At pH 5 approximately $90 \%$ of deacetylated primary amine groups of CS is protonated, causing electrostatic repulsion between adjacent CS molecules [58-60] and the presence of inter-molecular hydrogen bonding between the CS molecules keeps the CS chain in an intact form $[52,57,61]$.

In aqueous conditions, TPP dissociates into phosphate ions $\left(\mathrm{PO}_{4}{ }^{3-}\right)$ and hydroxide ions (OH-) [62]. Studies reported that TPP at $\mathrm{pH} 2$ enable the nanoparticles to participate controlled release mechanism compared to higher $\mathrm{pH}$ (i.e., 5 and 8.5) [63]. Besides, at lower $\mathrm{pH}$ (i.e., $\mathrm{pH}$ 2), only phosphate ions are formed, thus lesser $-\mathrm{NH}_{3}{ }^{+}$are deprotonated by anionic TPP, which leads to the formation of smaller and monodispersed CNP [52,61,62]. Conversely, at higher $\mathrm{pH}$, non-specific ionic gelation between both CS chains and existing CNP occur causing formation of agglomerated and larger-sized CNP due to presence of both $\mathrm{PO}_{4}{ }^{3-}$ and $\mathrm{OH}-[52,61,62]$. The centrifugation step which was carried prior to addition of TPP to CS is important to discard larger and agglomerated CS molecules and TPP, and thus ease the formation of small and monodispersed nanoparticles [52].

\subsection{Physicochemical Characterization of $C N P^{\circ}-C G A$ Nanoparticles}

The nutraceutical and antioxidant potential of CGA is overshadowed by poor compound stability and poor intracellular permeability. Administration of high dosage to encounter these deficits lead to many unexpected side effects $[28,35,64]$. Therefore, a CNP-mediated drug delivery system was adapted as a vector to encapsulate CGA as a cargo to improve its intracellular therapeutic efficacy. The close proximity between CGA and $-\mathrm{NH}_{3}{ }^{+}$of $\mathrm{CS}$ chains aid encapsulation of the compound within the core of $\mathrm{CNP}^{\circ}$ via electrostatic interaction [65]. Successful formation of $\mathrm{CNP}^{\circ}$-CGA hybrids was achieved using CGA concentrations $2 \mu \mathrm{M}, 10 \mu \mathrm{M}$, and $20 \mu \mathrm{M}$ determined through particle size distribution and PDI analysis, CGA encapsulation efficacy (CGA-EE\%), and CGA loading (CGA-L, $\mu M$ ) surmised in Table 2.

Table 2. The effects of different CGA final concentrations on polydispersity index, (PDI), average particle size distribution (diameter in $\mathrm{nm}, \mathrm{nm}$ ), and encapsulation efficiency percentage, (EE\%) of $\mathrm{CNP}^{\circ}$. Error bars represent the SD of three independent replicates of the experiment.

\begin{tabular}{ccccc}
\hline $\begin{array}{c}\text { Final } \\
\begin{array}{c}\text { Concentration of } \\
\text { CGA in CNP }\end{array}\end{array}$ & $\begin{array}{c}\text { Average Particle } \\
\text { Size Distribution, } \\
(\mathbf{n m})\end{array}$ & $\begin{array}{c}\text { Polydispersity } \\
\text { Index, (PDI) }\end{array}$ & $\begin{array}{c}\text { Encapsulation } \\
\text { Efficiency, (EE \%) }\end{array}$ & $\begin{array}{c}\text { CGA Loading, } \\
\text { (CGA-L, } \boldsymbol{\mu M})\end{array}$ \\
\hline $0 \mu \mathrm{M}\left(\mathrm{CNP}^{\circ}\right)$ & $80.89 \pm 5.16$ & $0.26 \pm 0.01$ & - & - \\
$2 \mu \mathrm{M}$ & $91.99 \pm 18.28$ & $0.30 \pm 0.04$ & $74.43 \pm 0.31$ & 1.49 \\
$10 \mu \mathrm{M}$ & $82.60 \pm 15.81$ & $0.28 \pm 0.06$ & $62.30 \pm 0.05$ & 6.23 \\
$20 \mu \mathrm{M}$ & $134.44 \pm 18.29$ & $0.29 \pm 0.03$ & $60.21 \pm 0.03$ & 12.04 \\
\hline
\end{tabular}

A prominent expansion in particle size was observed in CNP ${ }^{\circ}$-CGA samples as shown in Figure 4 upon encapsulation of $20 \mu \mathrm{M}$ of CGA $(134.44 \pm 18.29 \mathrm{~nm})$. This was a $66.20 \%$ increase in size compared to $2 \mu \mathrm{M}(91.99 \pm 18.28 \mathrm{~nm})$ and $10 \mu \mathrm{M}(82.60 \pm 15.81 \mathrm{~nm})$ CGA with only $13.72 \%$ and $2.11 \%$ of increase, respectively; possibly due to a higher availability of CGA for encapsulation. It was suggested that the drug-nanoparticle hybrid between the size range of 100-200 $\mathrm{nm}$ has a better 4-fold increased cellular uptake in cancer cells, enhanced encapsulation due to small surface area to volume ratio, partake in slow drug release rate mechanism, and could escape from spleen and liver filtration as compared to particles sized less than $50 \mathrm{~nm}$ and more than $300 \mathrm{~nm}$ [55,66-68]. A small increase in PDI values were perceived upon encapsulation of $2 \mu \mathrm{M}, 10 \mu \mathrm{M}$, and $20 \mu \mathrm{M}$ of CGA; from $0.26 \pm 0.01\left(\mathrm{CNP}^{\circ}\right)$ to $0.30 \pm 0.04$ (an increase of 15.38\%), $0.28 \pm 0.06$ (an increase of $7.69 \%$ ), and $0.29 \pm 0.03$ (an increase of $11.54 \%$ ), respectively. Presence of two types of particles in the hybrid, $\mathrm{CNP}^{\circ}$ and CGA, was also inferred through this slight increase in PDI value. 


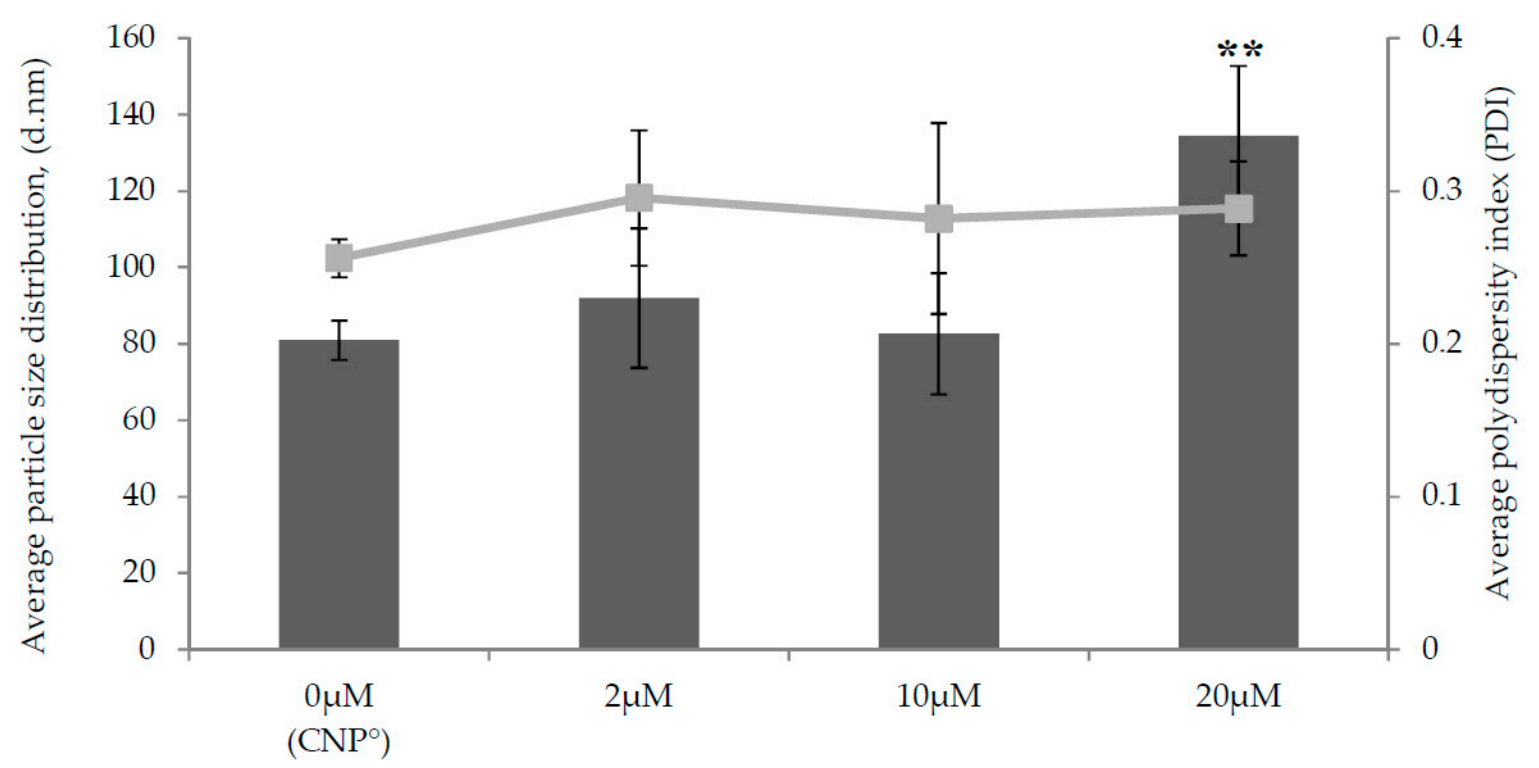

Final concentration of CGA in $\mathrm{CNP}^{\circ}$

Figure 4. Effect of different final concentrations of CGA on average particle size distribution (nm) and polydispersity index, (PDI) of $\mathrm{CNP}^{\circ}$. The average particle size distribution is illustrated in bar graph and PDI is illustrated in line graph. Error bars represent the SD of three independent replicates of the experiment. * shows degree of significant difference, $p<0.0086$ compared to control, $\mathrm{CNP}^{\circ}$.

Following the increase in CGA concentrations used for loading into $\mathrm{CNP}^{\circ} ; 2 \mu \mathrm{M}, 10 \mu \mathrm{M}$, and $20 \mu \mathrm{M}, \mathrm{CGA}-\mathrm{EE} \%$ (percentage of CGA successfully loaded into nanoparticle) showed a declining trend from $74.43 \pm 0.31 \%, 62.30 \pm 0.05 \%$, and $60.21 \pm 0.03 \%$, respectively, while CGA-L showed otherwise; $1.49 \mu \mathrm{M}, 6.23 \mu \mathrm{M}$, and $12.04 \mu \mathrm{M}$, respectively (as can be seen in Table 2). CGA-L is much more significant than CGA-EE\% as it represented the amount of CGA loaded per unit weight of $\mathrm{CNP}^{\circ}$, encapsulation of $20 \mu \mathrm{M} \mathrm{CGA}$ in $\mathrm{CNP}^{\circ}$ was found to be better compared to other concentrations as higher amounts of CGA were found to be encapsulated into per unit $\mathrm{CNP}^{\circ}$ weight. Evidently, formation of $\mathrm{CNP}^{\circ}$-CGA hybrids following loading of $200 \mu \mathrm{L}$ of $100 \mu \mathrm{M}$ (initial concentration) CGA, portrayed to be the optimal parameter as compared to $10 \mu \mathrm{M}$ and $50 \mu \mathrm{M}$ due to its significant particle size expansion, formation of stable, monodispersed CGA-nanoparticles hybrid, higher quantity of CGA encapsulated in per unit weight of CNP ${ }^{\circ}$.

According to Nagda et al. (2008) and Pavanveena et al. (2010), one factor that influences the amount of drug being entrapped within the nanoparticle is the drug to polymer ratio [69,70]. The higher this ratio, the lower the $\mathrm{EE} \%$. This inference ties well with this study, whereby three different ratios of CGA to CS were analyzed, i.e., 1:300 (for $2 \mu \mathrm{M}$ ), 1:60 (for $10 \mu \mathrm{M}$ ), and 1:30 (for $20 \mu \mathrm{M}$ ), showing that the EE\% decreased as the CGA:CS ratio increases. Consequently, CGA loading increased along with concentration of the compound, indicating that more compound was able to be loaded per unit weight of CNP.

\subsection{Morphological Characterization of $C N P^{\circ}$ and $C N P^{\circ}-C G A$ Samples}

Irregular, spherical-shaped and well dispersed $\mathrm{CNP}^{\circ}$ and $\mathrm{CNP}^{\circ}$-CGA accompanied by particle size range of 70-80 $\mathrm{nm}$ and above $100 \mathrm{~nm}$, respectively, were observed through Transmission Electron Microscopy (TEM) analysis in Figure 5A,B. The particles of CNP ${ }^{\circ}$-CGA were found to be stacked on one another with no apparent agglomerations of nanoparticles. Similar CNP morphology finding were reported previously by Raja et al. (2015) following loading of siRNA [71]. The CNP ${ }^{\circ}$ appeared darker in Figure 5A due to scattering or absorption of electrons by compact and condensed nanoparticles formed through ionic gelation between CS and TPP [72]. In contrast, following loading of CGA, the size of $\mathrm{CNP}^{\circ}$ increased due to interactions between CS with TPP and CGA via ionic gelation and 
electrostatic interactions. Formation of lighter or less dense region of $\mathrm{CNP}^{\circ}$-CGA (Figure 5B) may be due to transmittance of more electrons [72], while the dark shades inside the $\mathrm{CNP}^{\circ}$ could possibly illustrate the successful encapsulation of CGA.

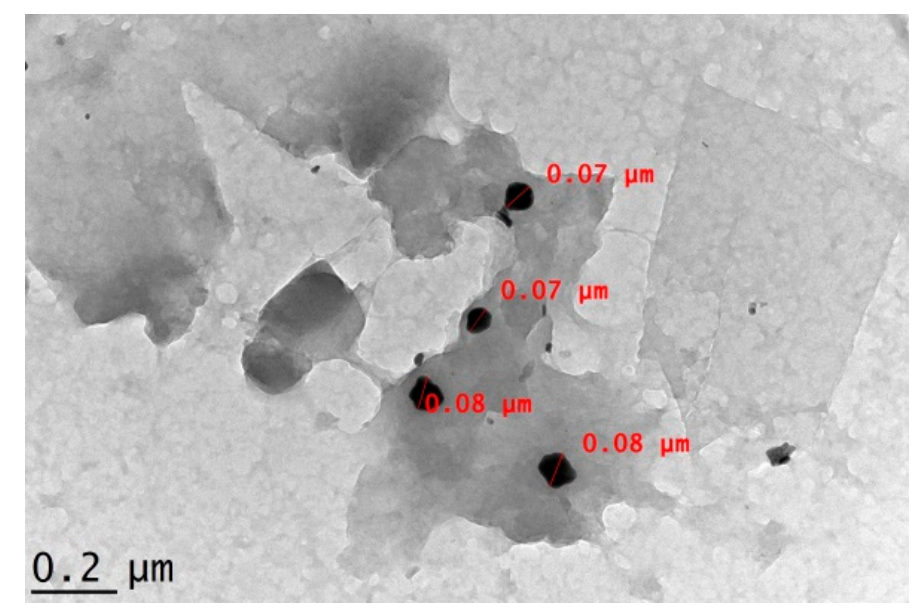

(A)

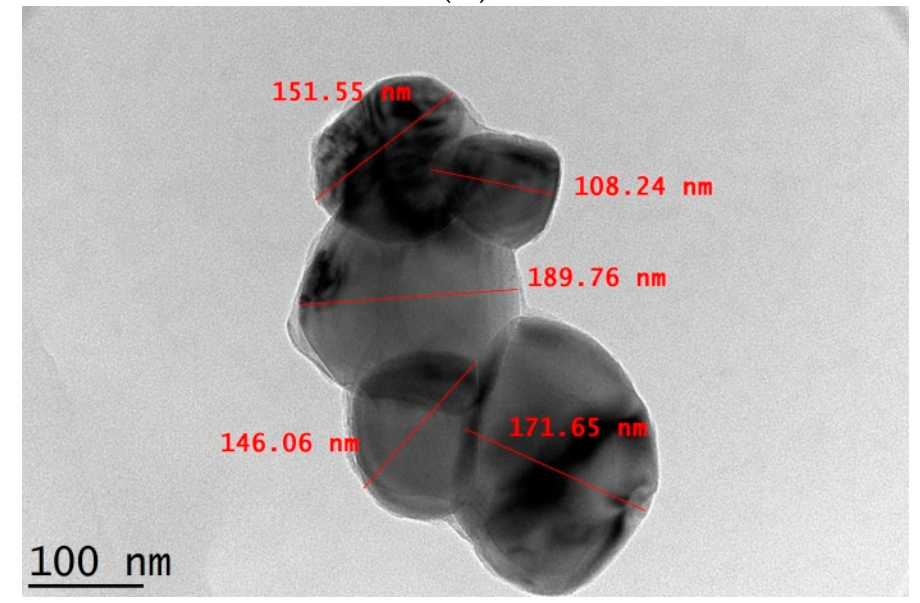

(B)

Figure 5. Images of Transmission Electron Microscopy (TEM) morphological analysis of (A) $\mathrm{CNP}^{\circ}$ and (B) $\mathrm{CNP}^{\circ}$-CGA. Particles appeared as irregular spherical-shape for all parameters used.

The Field Emission Scanning Electron Microscopy (FESEM) images of $\mathrm{CNP}^{\circ}$ and $\mathrm{CNP}^{\circ}$-CGA in Figure 6 A,B showed irregular spherical-shaped nanoparticles with particle size ranging from $40-90 \mathrm{~nm}$, and $80-160 \mathrm{~nm}$, respectively. The morphological image of $\mathrm{CNP}^{\circ}$ was found to be similar to studies by Luo et al. (2010), Chuah et al. (2013), and Ariff et al. (2017), hence verifying the formation of the nanoparticles [73-75]. Following encapsulation of CGA, the particle size of CNP ${ }^{\circ}$ increased two-folds, complimenting to particle size increase from $80.89 \pm 5.16 \mathrm{~nm}$ to $134.44 \pm 18.29 \mathrm{~nm}$ in the DLS analysis, hence confirming the formation of $\mathrm{CNP}^{\circ}$-CGA hybrids. Consequently, particle distribution analysis was performed to further correlate FESEM and DLS results $\mathrm{CNP}^{\circ}$ (Figure $7 \mathrm{~A}, \mathrm{~B}$ ) and $\mathrm{CNP}^{\circ}$-CGA (Figure $8 \mathrm{~A}, \mathrm{~B}$ ). The particle diameter of $\mathrm{CNP}^{\circ}$ and $\mathrm{CNP}^{\circ}$-CGA in Figure $6 \mathrm{~A}, \mathrm{~B}$ were manually measured and a normal distribution as well as frequency of the particle sizes were plotted, as shown in Figures 7B and $8 \mathrm{~B}$. Based on the plotted graphs, the particle size range of $\mathrm{CNP}^{\circ}$ and $\mathrm{CNP}^{\circ}$-CGA were $40-110 \mathrm{~nm}$ and 80-200 nm, respectively. While, the particle size frequency showed $\mathrm{CNP}^{\circ}$ were mostly measured between $50 \mathrm{~nm}$ and $70 \mathrm{~nm}$, and $\mathrm{CNP}^{\circ}$-CGA were in the range of $80 \mathrm{~nm}$ to $160 \mathrm{~nm}$; double the size range of $\mathrm{CNP}^{\circ}$. These results correspond to the DLS results of $\mathrm{CNP}^{\circ}(80.89 \pm 5.16 \mathrm{~nm})$ and $\mathrm{CNP}^{\circ}-\mathrm{CGA}$ $(134.44 \pm 18.29 \mathrm{~nm})$. 


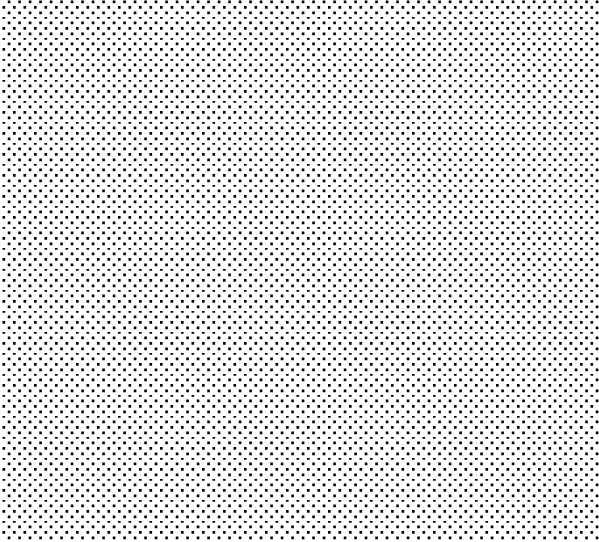

(A)

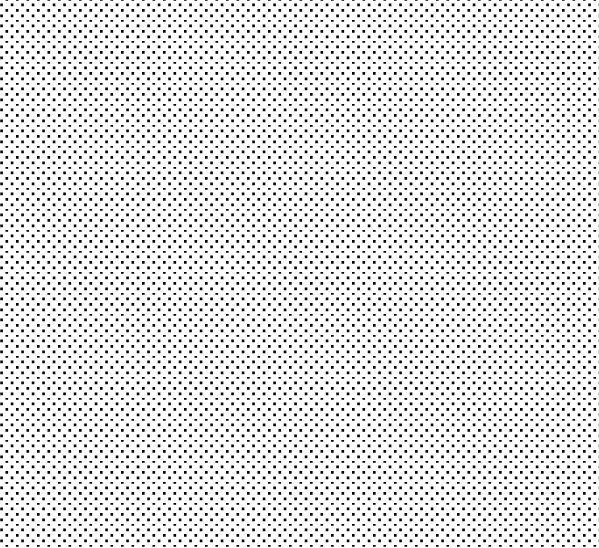

(B)

Figure 6. Images of FESEM morphological analysis of (A) $\mathrm{CNP}^{\circ}$ and (B) $\mathrm{CNP}^{\circ}$-CGA. Particles appeared as irregular, dispersed spherical-shape for all parameters.

\begin{tabular}{rllll} 
& & Diam. (nm) & \% Intensity & Width (nm) \\
Z-Average (d.nm): 74.00 & Peak 1: & 99.56 & 98.7 & 62.31 \\
Pdll: 0.253 & Peak 2: & 4604 & 1.3 & 827.3 \\
Intercept: 0.935 & Peak 3: & 0.000 & 0.0 & 0.000 \\
Result quality : Good & & & & \\
\hline
\end{tabular}

ize Distribution by Intensity
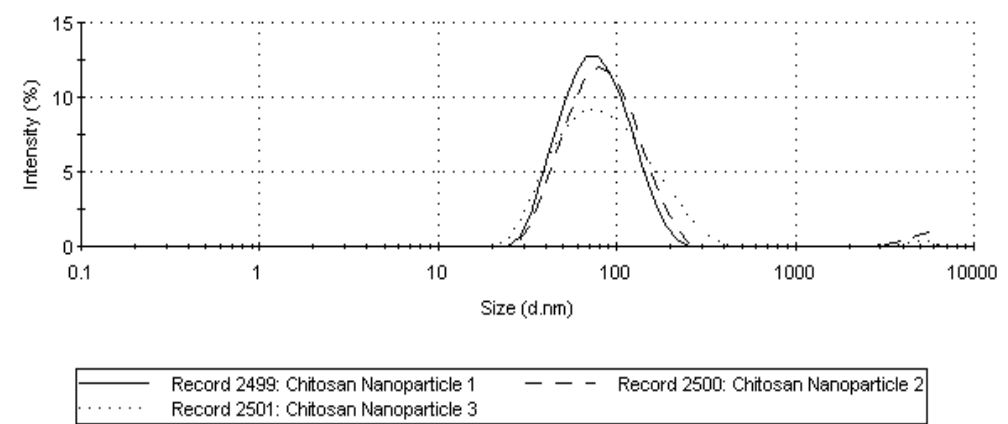

(A)

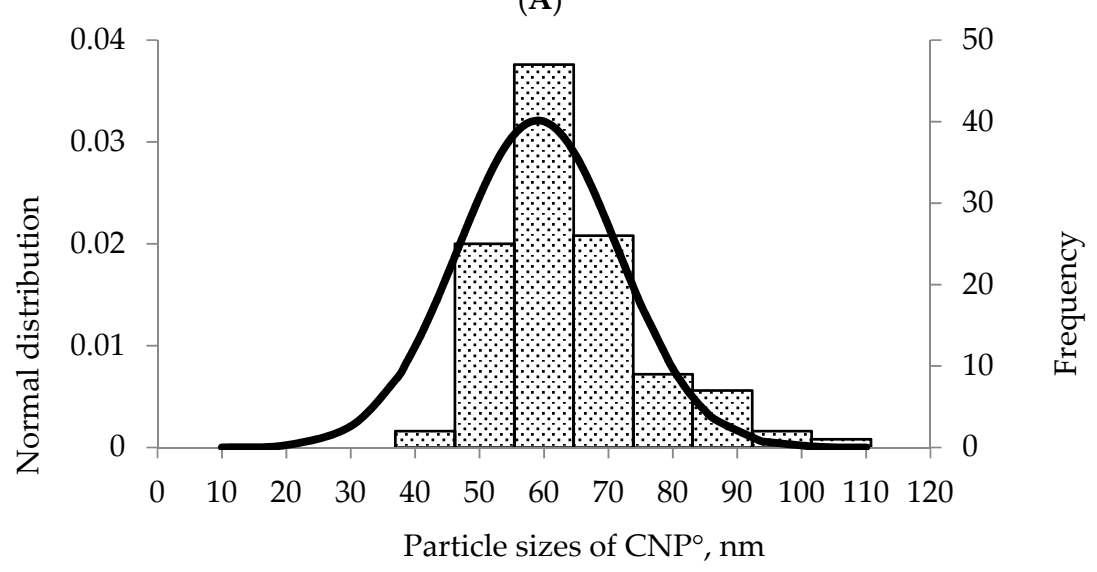

(B)

Figure 7. (A) Dynamic Light Scattering (DLS) result of $\mathrm{CNP}^{\circ}$ and (B) normal distribution and frequency graphs of $\mathrm{CNP}^{\circ}$ particle sizes $(\mathrm{nm})$ obtained by measuring particle size in FESEM image in (Figure 6A) using ImageJ software. Comparable particle size range of $\mathrm{CNP}^{\circ}$ was observed between DLS $(80.89 \pm$ $5.16 \mathrm{~nm}$ ) and FESEM (50 $\mathrm{nm}$ and $70 \mathrm{~nm}$ ). The slight difference between the two analysis is because DLS measures the particle size in hydrodynamic condition, while FESEM measures in a dry condition. 


$\begin{array}{rlllll} & & & \text { Diam. }(\mathbf{n m}) & \% \text { Intensity } & \text { Width }(\mathbf{n m}) \\ \text { Z-Average (d.nm): } & 116.2 & \text { Peak 1: } & 180.6 & 100.0 & 172.0 \\ \text { Pdl: } & 0.326 & \text { Peak 2: } & 0.000 & 0.0 & 0.000 \\ \text { Intercept: } & 0.932 & \text { Peak 3: } & 0.000 & 0.0 & 0.000 \\ \text { Result quality : } & \text { Good } & & & & \end{array}$

Size Distribution by Intensity

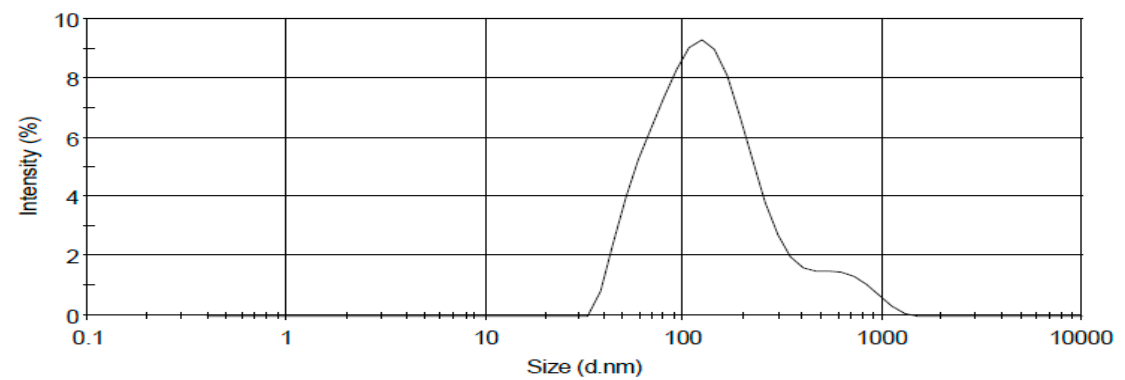

(A)

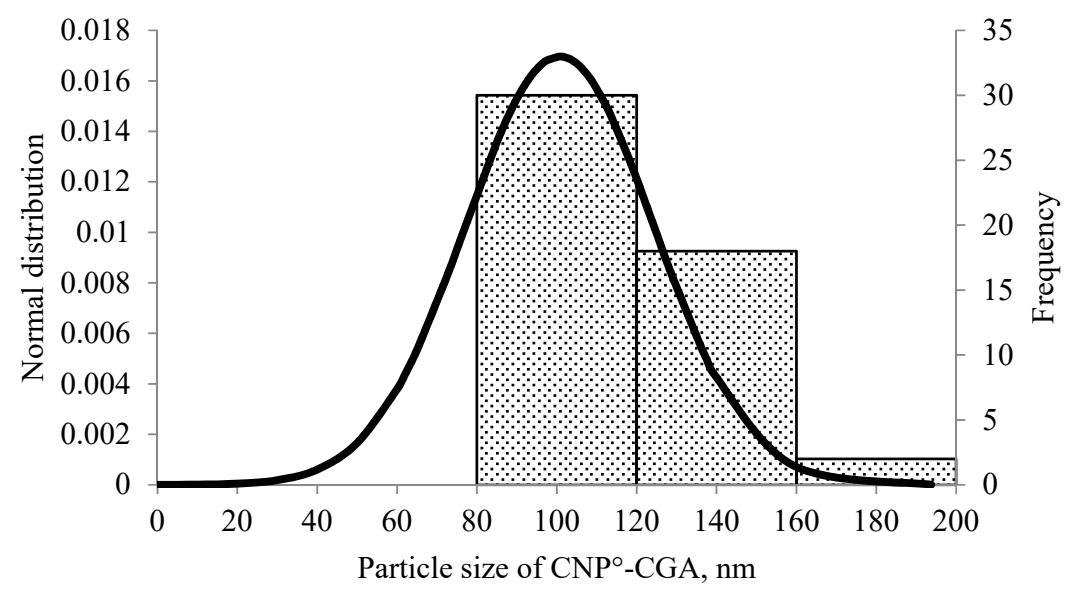

(B)

Figure 8. (A) DLS result of $\mathrm{CNP}^{\circ}$-CGA and (B) normal distribution and frequency graphs of $\mathrm{CNP}^{\circ}$-CGA particle sizes $(\mathrm{nm})$ obtained by measuring particle size in FESEM image in (Figure 6B) using Image software. Comparable particle size range of $\mathrm{CNP}^{\circ}$ was observed between DLS $(134.44 \pm 18.29 \mathrm{~nm})$ and FESEM ( $80 \mathrm{~nm}$ to $160 \mathrm{~nm}$ ). The slight difference between the two analysis is because DLS measures the particle size in hydrodynamic condition, while FESEM measures in a dry condition.

The particle size distribution result of FESEM slightly differ from the DLS analysis (Figures 4 and 6) as DLS measures the diameter of the nanoparticles based on scattering of light in its actual state (hydrodynamic condition) while FESEM is based on scattering of electrons in a dry condition [52]. Moreover, the consistency of particle size distributions and intact formation of nanoparticle shape were even perceived in both the FESEM images, implying that these properties were conserved upon encapsulation CGA.

\subsection{Functional Group Analysis of $C N P^{\circ}$ and $C N P^{\circ}-C G A$ Samples}

The functional groups attributed to FTIR spectrum of $\mathrm{CS}, \mathrm{TPP}, \mathrm{CNP}^{\circ}, \mathrm{CGA}$, and $\mathrm{CNP}^{\circ}$-CGA were illustrated in Figure 9 and summarized in a tabulated form in Table 3. The - $\mathrm{OH}$ and $-\mathrm{NH}_{2}$ stretching vibration of CS at $3353.91 \mathrm{~cm}^{-1}$ was observed in $\mathrm{CNP}^{\circ}$ at $3364.97 \mathrm{~cm}^{-1}$ and $C N P^{\circ}$-CGA at $3398.61 \mathrm{~cm}^{-1}$ possibly due to presence of intermolecular hydrogen bonds during the formation of nanoparticles and encapsulated nanoparticles $[60,76,77]$. While in TPP, the -OH stretching vibration was perceived at $3253.92 \mathrm{~cm}^{-1}$. 


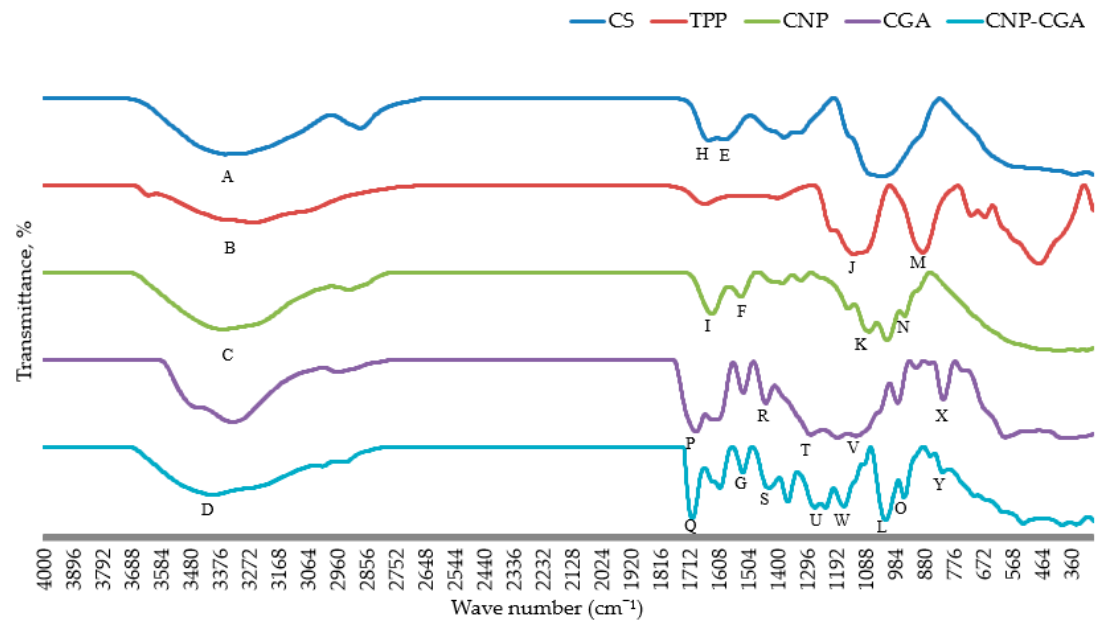

Figure 9. FTIR spectra of $\mathrm{CS}, \mathrm{TPP}, \mathrm{CNP}^{\circ}, \mathrm{CGA}$, and $\mathrm{CNP}^{\circ}$-GCA. The successful formation of $\mathrm{CNP}^{\circ}$ and $\mathrm{CNP}^{\circ}$-CGA were discerned through the presence of functional group peaks. Freeze dried samples were used to ensure sensitivity of analysis, also to remove non-specific background peaks. Alphabet labeling denotes important functional groups of samples, and is further elaborated in Table 3.

Table 3. Summary of functional groups present in FTIR spectra of CS, TPP, CNP ${ }^{\circ}, \mathrm{CGA}$, and $\mathrm{CNP}^{\circ}-\mathrm{GCA}$.

\begin{tabular}{|c|c|c|c|c|}
\hline Functional Group & Samples & $\begin{array}{l}\text { Wavenumber } \\
\left(\mathrm{cm}^{-1}\right)\end{array}$ & $\begin{array}{l}\text { Transmittance } \\
\text { Percentage (\%) }\end{array}$ & Figure 9 Label \\
\hline \multirow{4}{*}{$-\mathrm{OH} /-\mathrm{NH}_{2}$ stretching vibration } & CS & 3353.91 & 35.26 & $\mathrm{~A}$ \\
\hline & TPP & 3253.92 & 57.22 & $\mathrm{~B}$ \\
\hline & $\mathrm{CNP}^{\circ}$ & 3364.97 & 34.74 & $\mathrm{C}$ \\
\hline & $\mathrm{CNP}^{\circ}-\mathrm{CGA}$ & 3398.61 & 44.97 & $\mathrm{D}$ \\
\hline \multirow{3}{*}{ N-H bending, amide } & CS & 1587.00 & 52.24 & $\mathrm{E}$ \\
\hline & $\mathrm{CNP}^{\circ}$ & 1527.82 & 72.08 & $\mathrm{~F}$ \\
\hline & $\mathrm{CNP}^{\circ}-\mathrm{CGA}$ & 1520.64 & 70.60 & G \\
\hline \multirow{2}{*}{ Stretching of $\mathrm{C}=\mathrm{O}$, amide } & $\mathrm{CS}$ & 1641.06 & 51.11 & $\mathrm{H}$ \\
\hline & $\mathrm{CNP}^{\circ}$ & 1630.94 & 52.27 & $\mathrm{I}$ \\
\hline \multirow{3}{*}{ Stretching of $\mathrm{P}=\mathrm{O}$} & TPP & 1126.89 & 20.92 & $\mathrm{~J}$ \\
\hline & $\mathrm{CNP}^{\circ}$ & 1073.91 & 32.03 & K \\
\hline & $\mathrm{CNP}^{\circ}-\mathrm{CGA}$ & 1014.92 & 15.61 & $\mathrm{~L}$ \\
\hline \multirow{3}{*}{$\begin{array}{c}\text { Asymmetrical stretching vibration } \\
\text { of P-O-P }\end{array}$} & $\mathrm{TPP}$ & 883.70 & 22.73 & M \\
\hline & $\mathrm{CNP}^{\circ}$ & 948.77 & 49.86 & $\mathrm{~N}$ \\
\hline & $\mathrm{CNP}^{\circ}-\mathrm{CGA}$ & 949.14 & 41.68 & $\mathrm{O}$ \\
\hline \multirow{2}{*}{$\begin{array}{l}\mathrm{C}=\mathrm{O} \text { stretching vibration of } \\
\text { carboxyl and ester group }\end{array}$} & CGA & 1687.62 & 17.02 & $\mathrm{P}$ \\
\hline & $\mathrm{CNP}^{\circ}-\mathrm{CGA}$ & 1700.27 & 16.99 & Q \\
\hline \multirow{2}{*}{$\begin{array}{c}\text { Aromatic ring } \mathrm{C}=\mathrm{C} \text { stretching } \\
\text { vibration }\end{array}$} & CGA & 1439.88 & 49.94 & $\mathrm{R}$ \\
\hline & $\mathrm{CNP}^{\circ}-\mathrm{CGA}$ & 1428.52 & 52.90 & $\mathrm{~S}$ \\
\hline \multirow{2}{*}{$\begin{array}{l}\text { Stretching vibration of } \mathrm{C}-\mathrm{O}-\mathrm{C} \text { and } \\
\mathrm{C}-\mathrm{O} \text { of carboxyl and ester group }\end{array}$} & CGA & $1279.45,1185.17$ & $13.86,10.39$ & $\mathrm{~T}$ \\
\hline & $\mathrm{CNP}^{\circ}-\mathrm{CGA}$ & $1265.04,1228.71$ & $30.34,30.00$ & $\mathrm{U}$ \\
\hline \multirow{2}{*}{ Bending of $\mathrm{C}-\mathrm{H}$ and $\mathrm{COH}$} & CGA & 1119.50 & 12.37 & $\mathrm{~V}$ \\
\hline & $\mathrm{CNP}^{\circ}-\mathrm{CGA}$ & 1163.43 & 31.83 & $\mathrm{~W}$ \\
\hline \multirow{2}{*}{$\mathrm{CH}$ aromatic bending } & CGA & 810.46 & 53.71 & $x$ \\
\hline & $\mathrm{CNP}^{\circ}$-CGA & 812.13 & 70.81 & $\mathrm{Y}$ \\
\hline
\end{tabular}

Interestingly, two characteristic peaks of TPP; $\mathrm{P}=\mathrm{O}$ stretching peak at $1126.89 \mathrm{~cm}^{-1}$ and asymmetrical stretching vibration of $\mathrm{P}-\mathrm{O}-\mathrm{P}$ peak at $883.70 \mathrm{~cm}^{-1}$ were also apparent in $\mathrm{CNP}^{\circ}$ at $1073.91 \mathrm{~cm}^{-1}$ and $948.77 \mathrm{~cm}^{-1}$, respectively, and in CNP'-CGA at $1014.92 \mathrm{~cm}^{-1}$ and $949.14 \mathrm{~cm}^{-1}$ respectively [60,77-79]. These two peaks were not found in the CS spectrum; suggesting presence 
of these functional groups in $\mathrm{CNP}^{\circ}$ and $\mathrm{CNP}^{\circ}$-CGA were influenced by the ionic gelation between phosphate moiety of TPP and primary amine groups of CS $[8,76,77,80,81]$. Besides, the CS peaks associated to $\mathrm{C}=\mathrm{O}$ of amide I stretching $\left(1641.06 \mathrm{~cm}^{-1}\right)$ and $\mathrm{N}-\mathrm{H}$ bending vibration in amide II $\left(1587.00 \mathrm{~cm}^{-1}\right)$ was identified in $\mathrm{CNP}^{\circ}$ at peak $1630.94 \mathrm{~cm}^{-1}$ and peak $1527.82 \mathrm{~cm}^{-1}$, respectively, which was also perhaps due to TPP and CS cross-linking [60,76-78,82,83].

The encapsulation of CGA in $\mathrm{CNP}^{\circ}$ vector was discerned via the presence of five peaks attributed to $\mathrm{CGA}$ in the $\mathrm{CNP}^{\circ}$-CGA spectrum, which initially were absent in the $\mathrm{CNP}^{\circ}$ spectrum. Aromatic ring $\mathrm{C}=\mathrm{C}$ stretching vibration at $1439.88 \mathrm{~cm}^{-1}, \mathrm{C}=\mathrm{O}$ stretching vibration of carboxyl and ester group at $1687.62 \mathrm{~cm}^{-1}$, stretching vibration of C-O-C and C-O of carboxyl and ester group at $1279.45 \mathrm{~cm}^{-1}$ and $1185.17 \mathrm{~cm}^{-1}$, bending of $\mathrm{C}-\mathrm{H}$ and $\mathrm{COH}$ at $1119.50 \mathrm{~cm}^{-1}$, and $\mathrm{CH}$ aromatic bending at $810.46 \mathrm{~cm}^{-1}$ of CGA spectrum were spotted in CNP'-CGA spectrum at $1428.52 \mathrm{~cm}^{-1}, 1700.27 \mathrm{~cm}^{-1}, 1265.04 \mathrm{~cm}^{-1}$ and $1228.71 \mathrm{~cm}^{-1}, 1163.43 \mathrm{~cm}^{-1}$, and $812.13 \mathrm{~cm}^{-1}$, respectively [31,38,39,84-88].

Additionally, an increase in transmittance percentages of the $\mathrm{N}-\mathrm{H}$ bending of amide II peak in CS, $52.24 \%$, and P-O-P asymmetrical stretching vibration peak in TPP, $22.73 \%$ was observed upon formation of $\mathrm{CNP}^{\circ}, 72.08 \%$ and $49.86 \%$, respectively; may indicate the ionic interaction between TPP and CS. However, scarcely any changes in transmittance percentage of those two functional groups were perceived in $\mathrm{CNP}^{\circ}$-CGA $(70.60 \%$ and $41.68 \%$, respectively), implying the energy transmittances were not affected by the electrostatic interactions between CGA and CS during the formation of CGA-nanoparticle hybrids. Hence, this supports the successful formations of $\mathrm{CNP}^{\circ}$ and $\mathrm{CNP}^{\circ}$-CGA.

\subsection{Assessment of Antioxidant Potentials of CGA and CNP ${ }^{\circ}-C G A$}

The ability of CGA and CNP ${ }^{\circ}$-CGA to reduce DPPH into DPPH-H form was measured and compared to access their respective antioxidant strength. The common standard reference, ascorbic acid, was used. The concentration for all three samples, CGA, CNP ${ }^{\circ}$-CGA and ascorbic acid were limited to $12 \mu \mathrm{M}$ (on the graph) as the CGA-EE\% as $60.21 \pm 0.03 \%$, assuming approximately $60 \%$ of CGA was successfully encapsulated. As shown in Figure 10, a dose-dependent DPPH scavenging trend was observed among CGA, CNP ${ }^{\circ}$-CGA, and ascorbic acid postulating more DPPH radicals was reduced along with an increase in antioxidants concentration [89-91].

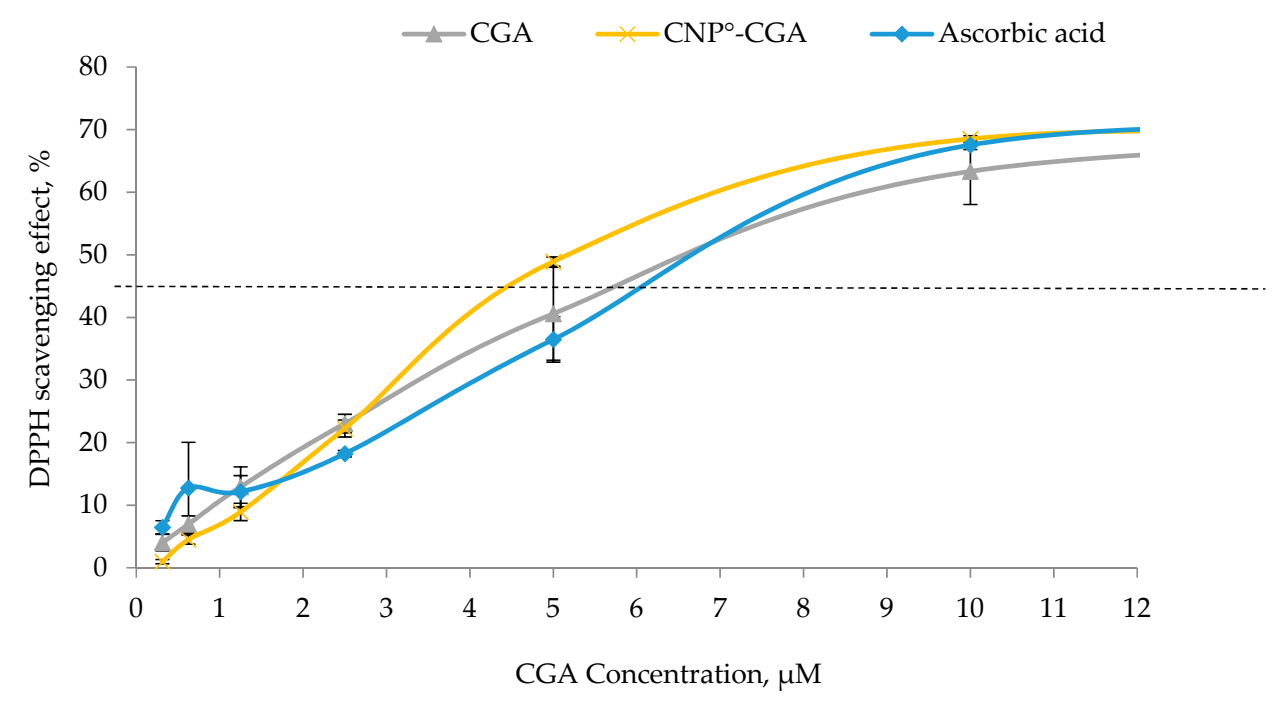

Figure 10. Antioxidant capacity of CGA, CNP ${ }^{\circ}$-GCA and ascorbic acid as standard at different concentrations. Error bars represent the SD of three independent replicates of the experiment. Dotted line indicates the $\mathrm{IC}_{50}$.

Ascorbic acid reached its scavenging effect plateau point at $11 \mu \mathrm{M}$, with $70 \%$ of DPPH scavenged. Remarkably, similar scavenging plateau point was observed at $\mathrm{CNP}^{\circ}$-CGA; suggesting a maximum of $11 \mu \mathrm{M}$ of $\mathrm{CNP}^{\circ}$-CGA was required to scavenge $0.1 \mathrm{mM}$ DPPH-as can be observed from 
Figure 10-whilst the plateau point of CGA was not seen; instead the scavenging activity continued rising even after $12 \mu \mathrm{M}$. We postulate that $\mathrm{CNP}^{\circ}$-CGA has better antioxidant strength than CGA, as it could scavenge DPPH much faster with lower concentration.

CGA compound could actively partake in scavenging activity due to its two hydroxyl groups at ortho position of its catechol; as claimed by Valgimigli et al. (2008) [92]. However, the antioxidant strength of CGA was prominently slower than CNP ${ }^{\circ}$-CGA possibly due to its formation $\pi$-stacking between of catechol of CGA through strong $\mathrm{OH}-\mathrm{H}$ or weak $\mathrm{OH}-\pi$ bonds; which might affect the transfer of $\mathrm{H}$ atom to scavenge the DPPH $[93,94]$. This phenomenon did not occur or minimized in $\mathrm{CNP}^{\circ}$-CGA as $\mathrm{CNP}^{\circ}$ gives a good spatial orientation for CGA, perhaps the reason for better scavenging activity. Conversely, the scavenging activity of $\mathrm{CNP}^{\circ}$ was below $10 \%$; implying the vector itself is weak antioxidant as similarly reported $[95,96]$ and therefore did not contribute towards the increased antioxidant efficiency in $\mathrm{CNP}^{\circ}$-CGA sample.

The $\mathrm{IC}_{50}$ values of pure CGA and $\mathrm{CNP}^{\circ}$-CGA, the minimum antioxidant concentration needed to scavenge 50\% of DPPH radicals, are shown in Figure 10. Ascorbic acid displayed an approximate $\mathrm{IC}_{50}$ value of $6.5 \mu \mathrm{M}$ similar to CGA, while $\mathrm{CNP}^{\circ}$-CGA displayed a slightly lower $\mathrm{IC}_{50}$ of $5 \mu \mathrm{M}$. We deduced that the encapsulated CGA has a better antioxidant strength as its scavenging activity was still conserved, and comparatively less CGA concentration was needed to scavenge $50 \%$ of DPPH than CGA to achieve similar scavenging activity.

\subsection{In Vitro $f C N P^{\circ}-C G A$ Uptake in Human Renal Adenocarcinoma 786-O Cells}

Time-dependent in vitro uptake of FITC labeled $\mathrm{CNP}^{\circ}$-CGA $\left(f \mathrm{CNP}^{\circ}\right.$-CGA) in 786-O cell line was studied through fluorescent microscopic and flow cytometry analyses. FITC has the ability to conjugate with the primary amine group of CS through covalent bonding without dissociating and provides a sensitive study on cellular accumulation efficiency of fluorescently labeled nanoparticles under the influence of time (30 $\mathrm{min}, 6 \mathrm{~h}, 24 \mathrm{~h}$, and $48 \mathrm{~h}$ ) [52,97]. Supplementary 1 showed that the uptake of $f \mathrm{CNP}^{\circ}$-CGA in 786-O cells was time-dependent, as the fluorescent intensity increased consequently with incubation time. Cellular uptake of $f \mathrm{CNP}^{\circ}$-CGA was detected as early as $30 \mathrm{~min}$ (Supplementary 1C) post-treatment with weak fluorescent signals outlining the cells membrane observed; a small portion of $f \mathrm{CNP}^{\circ}$-CGA being taken up by $786-\mathrm{O}$ cells. The fluorescent intensity in the cells thereafter increased in $6 \mathrm{~h}$ (Supplementary 1D), $24 \mathrm{~h}$ (Supplementary 1E), and $48 \mathrm{~h}$ (Supplementary $1 F)$ post-incubation treatments.

Conversely, smearing of the green fluorescent within the cells was observed at $24 \mathrm{~h}$, and $48 \mathrm{~h}$ post-treatment, possibly due to the dissociation of FITC from CNP $^{\circ}$-CGA [52]. It also indicated that CNP was effectively internalized by the cells; a slow degradation of CNP surface over time led to a release of encapsulated biomolecules (FITC and CGA) via a burst release model (releasing CGA close to the surface of $\mathrm{CNP}^{\circ}$ ) and erosion release model (releasing the encapsulated CGA) [98-102]. In in vitro studies, cultured cells propagated in media are exposed to high levels of lactic acid, which may decrease the intracellular $\mathrm{pH}$ environments. This lower $\mathrm{pH}$ condition protonates more amine groups of $\mathrm{CNP}^{\circ}$ causing its encapsulated contents to be dissociated and released intracellularly [103-105]. Hypothetically, in in vivo condition the degradation of the vector likely be aided by the lysozyme activity or swell under the influence of endosome or lysosome $\mathrm{pH}$ [106-109]. On the other hand, the uptake of $f \mathrm{CNP}^{\circ}$-CGA into the 786-O cells was solely dependent on the nanoparticle and not influenced by presence of the FITC, as no fluorescent signal was detected in control cells or at $48 \mathrm{~h}$ of post-treatment with FITC only. This also meant that the fluorophore can only enter the cells by conjugation with the nanoparticle. Similar observations were observed in studies by Ma et al. (2003), Jia et al. (2009), and Masarudin et al. (2015) [27,52,110].

Complimenting fluorescent microscopic analysis, flow cytometry analysis was performed as shown in Figure 11. A shift in the peak was observed at 30 min post-treatment (Figure 11C), describing about $99.28 \%$ of cells were outlined or accumulated by $f \mathrm{CNP}^{\circ}$-CGA. The peak continued to shift and percentage increased as the incubation period was prolonged to $6 \mathrm{~h}(99.89 \%)$ (Figure 11D), $24 \mathrm{~h}(99.93 \%)$ 
(Figure 11E), and $48 \mathrm{~h}(99.69 \%)$ (Figure 11F); signifying persistency in uptake of $f \mathrm{CNP}^{\circ}$-CGA across 786-O cell membranes. A slight decrease in FITC intensity percentage at $48 \mathrm{~h}$ could probably be due to instrument error. Additionally, high-sharp peak at $24 \mathrm{~h}$ and $48 \mathrm{~h}$ post-treatments were possibly due to the limit of the instrument (FITC intensity of $10^{7}$ ). Hypnotizing that the uptake of $f C \mathrm{NP}^{\circ}$-CGA could prolong till cells reaches the saturation point without the instrument limit. The $48 \mathrm{~h}$ post-treatment of FITC only peak overlapped with the control peak (cells only) as shown in Figure 11B, deducing no fluorescent signal was detected in or around the 786-O cells and FITC did not influence the cellular uptake of nanoparticles.

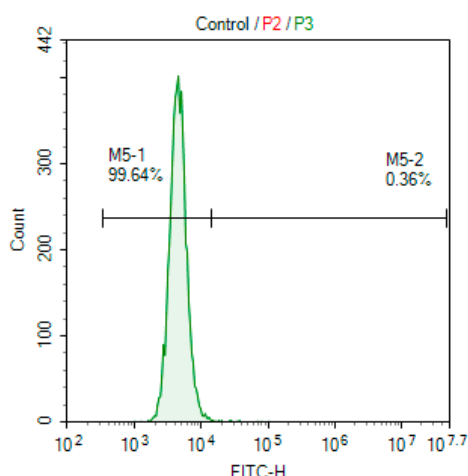

(A)

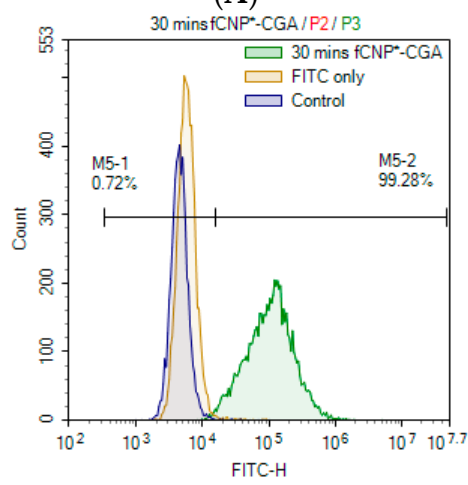

(C)

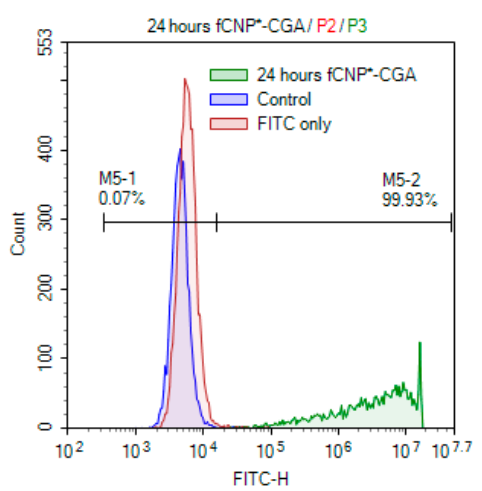

(E)

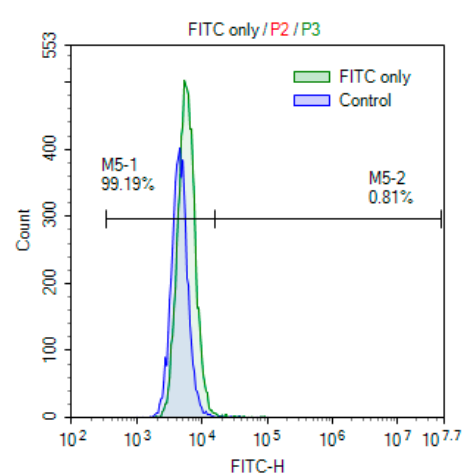

(B)

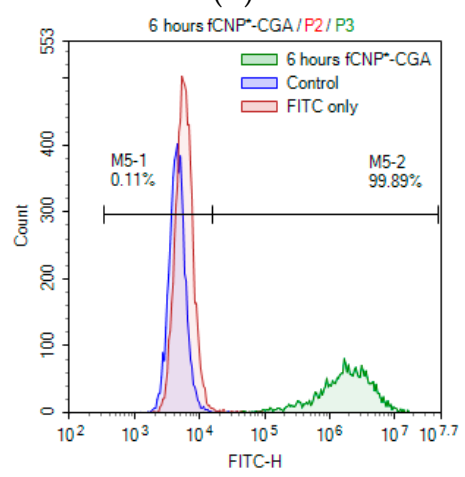

(D)

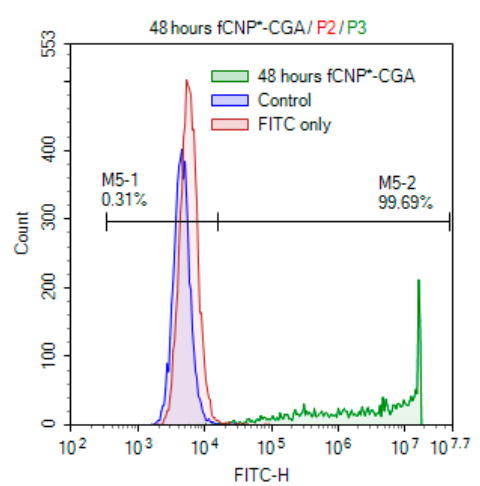

(F)

Figure 11. Flow cytometry study of in vitro accumulation of $f \mathrm{CNP}^{\circ}$-CGA in 786-O cells at (C) $30 \mathrm{~min}$, (D) $6 \mathrm{~h}$, (E) $24 \mathrm{~h}$, and (F) $48 \mathrm{~h}$. Overlap peaks of particular time point on (A) control and (B) FITC only peaks were shown in each figure to show the accumulation of $f \mathrm{CNP}^{\circ}$-CGA in $786-\mathrm{O}$ cells. The accumulation of $f \mathrm{CNP}^{\circ}$-CGA in 786-O cells showed a time-dependent trend, indicated through the increase of fluorescent intensity over time. Accumulation of $f \mathrm{CNP}^{\circ}$-CGA was observed as early as $30 \mathrm{~min}(\mathbf{C})$ and subsequently increased $6 \mathrm{~h}, 24 \mathrm{~h}$, and $24 \mathrm{~h}$ post treatment (D-F). 
One of the main deficits of CGA is its poor cellular permeability, halting this antioxidant-rich compound from exhibiting it chemopreventive mechanism. The hypothesis whereby nanoparticles could possibly aid this compound to improve its cellular permeability was proven through these two analyses, the microscopic viewing and flow cytometry analysis. These two studies are very crucial to demonstrate the facilitation of $\mathrm{CNP}^{\circ}$ in internalizing CGA into cells. There is the possibility that as more CGA compounds are internalized within the cells, it could carry out its chemopreventive activity more efficiently without being expelled from the system as described by Olthof et al. (2001), Gonthier et al. (2003), and Farah et al. (2008) in their respective studies [1,28,29].

Furthermore, multiple studies have supported the idea that the uptake of drug-nanoparticles hybrids were mainly influenced by particle size and the cellular uptake route. In this study, $\mathrm{CNP}^{\circ}$-CGA were synthesized with an average size of $134.44 \pm 18.29 \mathrm{~nm}$ which falls within the favorable size range $(50-200 \mathrm{~nm})$ for an efficient cellular uptake $[66,68]$ most likely to be taken up through the cell membranes through clathrin-mediated endocytosis mechanisms [27,111-113].

\subsection{Cytotoxicity Analysis of $C N P^{\circ}, C G A$, and $C N P^{\circ}-C G A$}

The MTT mediated cytotoxic assay was performed to study and compare the in vitro toxicity properties of the synthesized nanoparticles and drug-nanoparticles. Based on Figure 12, approximately $81.37 \pm 0.84 \%$ of $786-\mathrm{O}$ cells was viable $24 \mathrm{~h}$ post-treatment using $\mathrm{CNP}^{\circ}$ and thus; exhibited non-toxic properties in cells at the highest dose. Viability continued to increase up to $100 \%$ as the concentration of $\mathrm{CNP}^{\circ}$ decreased, a trend similarly reported by Jia et al. (2009) and Masarudin et al. (2015), thus suggesting $\mathrm{CNP}^{\circ}$ as a potential safe drug delivery vector $[52,110]$.

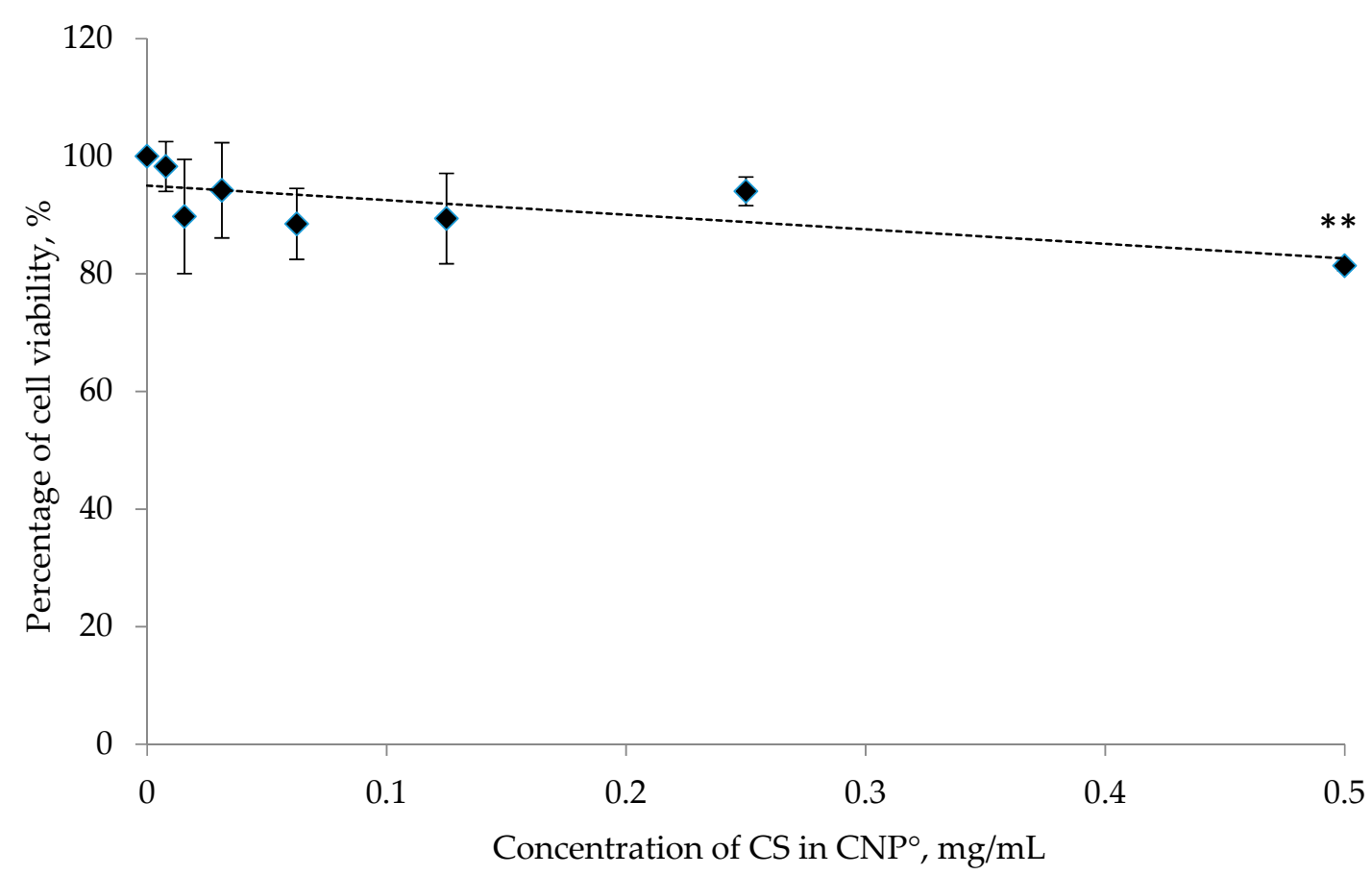

Figure 12. In vitro cytotoxicity test of $\mathrm{CNP}^{\circ}$ at different concentrations. Error bars represent the $\mathrm{SD}$ of three independent replicates of the experiment. At the highest dosage, $\mathrm{CNP}^{\circ}$ appeared to be non-toxic to 786-O cells upon $24 \mathrm{~h}$ post-treatment. * shows degree of significant difference, $P<0.0305$ compared to control.

The naturally existing antioxidant-rich polyphenolic, CGA $[2,114]$ has been actively studied as a chemopreventive agent. CGA has an ability to scavenge oncogenesis-inducing free radicals, facilitated by the catechol structure of CGA acting as the primary binding site for free radicals [9,10]. CGA has two to three-fold DPPH (1,1-diphenyl-2-picrylhydrazine) radicals scavenging activity and 10 to 30-fold 
superoxide anion radical scavenging activity as compared to vitamin C and E [14]. The binding sites of CGA does not only scavenges the oxygen and nitrogen species, but it also chelates metal ions, inhibits lipid oxidation, and hinders formation of free radicals [10-13,115].

Evidently, studies have reveal the ability of CGA to inhibit NF- $\mathrm{kB}$ transcription factor, repress DNA methylation, induce Nrf2 mediated antioxidant and detoxification enzymes (such as glutathione S-transferases (GST) and NAD(P)H: quinone oxidoreductase 1 (NQO1)) through antioxidant response element (ARE) to reduce oxidative stress cellular damages, and so on Reference [116-118]. Noratto et al. (2009) showed that CGA able to suppress the proliferation of MDA-MB-435, breast cancer cells, while Jin et al. (2005) managed to inhibit matrix metalloproteinase responsible for metastasis and invasion of cancer cell using CGA $[119,120]$.

Contrariwise, CGA is also known for its poor cellular permeability profile, loses its reliability as a potential nutraceutical compound $[1,28,29]$. Corresponding result was observed through the MTT assay analysis as shown in Figure 13; CGA appeared to be non-toxic to 786-O cell line. The percentages of cell viability were more than $100 \%$ at different CGA concentration ranged from $0 \mu \mathrm{M}$ to $12 \mu \mathrm{M}$ (Figure 13). Similar results were shown by Barahuie et al. (2013) and Barahuie et al. (2014), CGA acted as non-toxic compound towards 3T3 (mouse fibroblast normal cells), HeLa (human cervix adenocarcinoma) and MCF-7 (human mammary gland adenocarcinoma) cell lines even at maximum concentration of $50 \mu \mathrm{g} / \mathrm{mL} \mathrm{CGA}[31,88]$. We have strongly concluded that CGA is a non-toxic compound maybe due to its negative surface charges that hinders its uptake across 786-O cell membranes.

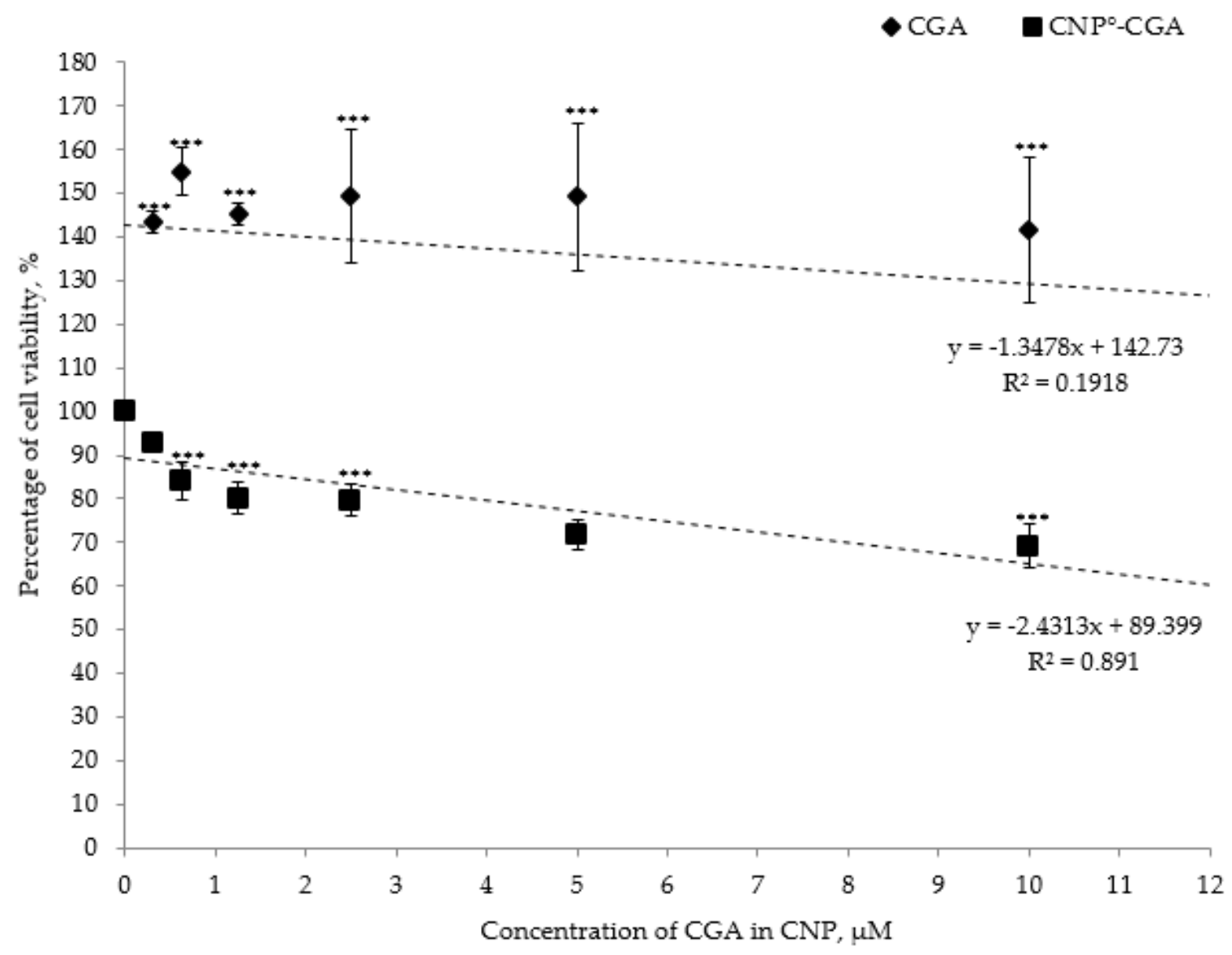

Figure 13. In vitro cytotoxicity test of $\mathrm{CGA}$ and $\mathrm{CNP}^{\circ}-\mathrm{CGA}$ at different concentrations. Error bars represent the SD of three independent replicates of the experiment. CGA alone was found to be non-toxic even at its highest dosage of $12 \mu \mathrm{M}$ ( $24 \mathrm{~h}$ post-treatment). Conversely, a noticeable dose-dependent decrease in 786-O cell viability were observed upon encapsulation of CGA in $\mathrm{CNP}^{\circ}$. * shows degree of significant difference, $p<0.0001$ compared to control. 
On the other hand, a significant shift in cytotoxicity effect on 786-O cell lines was observed following encapsulation of CGA in $\mathrm{CNP}^{\circ}$ vector. The concentrations of CGA and CNP ${ }^{\circ}$-CGA used were again limited to $12 \mu \mathrm{M}$ because of the maximum CGA-EE\% of $60 \%$. On the whole, the cell viability decreased in dose-dependent modus upon $24 \mathrm{~h}$ post-treatment of $\mathrm{CNP}^{\circ}$-CGA (Figure 13). Approximately $60.22 \%$ viable cells were detected at $12 \mu \mathrm{M}$ of $\mathrm{CNP}^{\circ}$-CGA; suggesting that encapsulation of CGA able to provide a better route to deliver CGA intracellularlly and subsequently enhance its bioavailability and therapeutic efficacy.

The shift in cytotoxic effect of CGA following encapsulation in nanoparticles was possibly due to positive surface charge of the vector contributed by the unconjugated protonated amine groups, and this cationic charge was hypothesized to be conserved even after encapsulating CGA. Additionally, this feature of the vector enables it to participate clathrin-mediated endocytosis route to permeate across the anionic cell membrane $[8,52,111,121,122]$. Additionally, $\mathrm{IC}_{50}$ of CGA and CNP ${ }^{\circ}$-CGA were approximately calculated; $68.80 \mu \mathrm{M}$ and $16.20 \mu \mathrm{M}$, respectively. An approximately 4-fold more CGA concentration was needed to achieve similar cytotoxic effect as $\mathrm{CNP}^{\circ}$-CGA. Deducing the encapsulated CGA potentially reduced the need for high dosage administrations of CGA to the cell line.

\section{Materials and Methods}

\subsection{Materials}

All materials were purchased and used without further purification, unless otherwise stated. Low molecular weight chitosan (CS) powder, sodium tripolyphosphate (TPP) powder, sodium dodecyl sulfate (SDS) powder, 2,4,6-trinitrobenzene sulfonic acid (TNBS) powder, L-ascorbic acid powder, 1,1-Diphenyl-2-picrylhydrazine 97\%, (DPPH) powder, fluorescein 5(6)-isothiocyanate (FITC) powder, thiazolyl blue tetrazolium bromide (MTT) powder, phosphate buffered saline (10x) (PBS) solution, dimethyl sulfoxide (DMSO) solution, ethylenediaminetetraacetic acid (EDTA), and sodium carbonate powder, were purchased from Sigma-Aldrich (St Louis, MO, USA). Hydrochloric acid solution, sodium hydroxide pellet, and glacial acetic acid solution, and chlorogenic acid (CGA) powder were purchased from Friendmann Schmidt Chemicals (Germany). Methanol solution, reagent grade AR was purchased from QReC (New Zealand). RPMI medium 1640 (1×) solution, Fetal Bovine Serum (FBS) solution, antibiotic-antimycotic $(100 \times)$ solution, and $0.25 \%$ Trypsin-EDTA $(1 \times)$ solution were purchased from Gibco, Life Technologies (Grand Island, NY, USA).

\subsection{Synthesis of Chitosan Nanoparticles, CNP}

Chitosan nanoparticles (CNP) were prepared based on modified ionic gelation method of Calvo et al. (1997) [123]. One $\mathrm{mg} / \mathrm{mL}$ stock solutions of chitosan (CS) and sodium tripolyphosphate (TPP) were prepared before diluting them to desired working solution as described in Table 1. CS stock solution was prepared by overnight stirring of $25 \mathrm{mg}$ of low molecular weight chitosan powder in $1 \mathrm{~mL}$ of $1 \%$ acetic acid aqueous solution and $24 \mathrm{~mL}$ of sterile distilled water $\left(\mathrm{sdH}_{2} \mathrm{O}\right)$, while TPP stock solution was prepared simply by dissolving $25 \mathrm{mg}$ of TPP powder in $\mathrm{sdH}_{2} \mathrm{O}$. The working solutions of CS and TPP were diluted to three different concentrations as shown Table 1. Subsequently, $\mathrm{pH}$ of the CS, and TPP solutions were adjusted to $\mathrm{pH} 5$ (using $1 \mathrm{M} \mathrm{NaOH}$ ), and pH 2 (using $1 \mathrm{M} \mathrm{HCl}$ ) respectively, prior to centrifugation at $4000 \mathrm{rpm}$ for $45 \mathrm{~min}$ at room temperature. CNP of different formulations were synthesized by adding increasing volume of TPP cross-linkers ranging from 20 $\mu \mathrm{L}$ to $300 \mu \mathrm{L}$, to $600 \mu \mathrm{L}$ of CS. The CNP samples were incubated at room temperature, and used in subsequent analysis.

\subsection{Quantification of Free Amines in CNP Formulations}

$\mathrm{CNP}$ was formed via ionic gelation between protonated primary amine groups $\left(-\mathrm{NH}_{3}{ }^{+}\right)$of $\mathrm{CS}$ and anionic phosphate groups (- $\left.\mathrm{PO}_{4}{ }^{3-}\right)$ of TPP cross-linker. A slightly modified TNBS (2,4,6-trinitrobenzene sulfonic acid) assay protocol of Masarudin et al. (2015) was adapted to quantify the percentage of 
unconjugated primary amine group $\left(-\mathrm{NH}_{3}{ }^{+}\right)$in CNP formulations [52]. Freshly prepared $0.1 \mathrm{M}$ sodium carbonate $\left(\mathrm{NaCO}_{3}\right)$ at $\mathrm{pH} 8.5,10 \%$ sodium dodecyl sulfate (SDS), $1 \mathrm{M}$ hydrochloric acid $(\mathrm{HCl})$, and $0.05 \%$ TNBS in $0.1 \mathrm{M} \mathrm{NaCO}_{3}$ at $\mathrm{pH} 8.5$ were used for this assay. Serially diluted CS solution using $\mathrm{NaCO}_{3}(0.1 \mathrm{M}, \mathrm{pH} 8.5)$ were used as standards. CNP solutions were prepared based on the formulations in Table 1. Hundred microliters of TNBS at $0.05 \%$ concentration was mixed thoroughly into $100 \mu \mathrm{L}$ of CS sample (control) and CNP samples, and incubated in water bath at $37^{\circ} \mathrm{C}$ for $3 \mathrm{~h}$. Upon incubation, $100 \mu \mathrm{L}$ of each sample, $100 \mu \mathrm{L}$ of $10 \%$ SDS, and $75 \mu \mathrm{L}$ of $1 \mathrm{M}$ hydrochloric acid, $(\mathrm{HCl})$ were pipetted into wells of 96-well plate. Mixture of $50 \mu \mathrm{L}$ of $0.1 \mathrm{M} \mathrm{NaCO}_{3}$ at $\mathrm{pH} 8.5,100 \mu \mathrm{L} 10 \% \mathrm{SDS}$, and $75 \mu \mathrm{L}$ of $0.1 \mathrm{M} \mathrm{HCl}$ solution was set as blank. The samples were analyzed at $\mathrm{A}_{335}$ using microplate reader (Bio-Tek Instrument, Winooski, VT, USA). The percentage of free amine group was quantified using the following formula;

$$
\text { Free amine group, } \%=\frac{\text { Absorbance of sample }}{\text { Absorbance of control }} \times 100 \%
$$

\subsection{Measurement of Particle Size Distribution, and Polydispersity (PDI) of Nanoparticle Samples}

The formation of nanoparticles, particle size distributions and PDI value of the synthesized CNP samples were measured via dynamic light scattering (DLS) analysis using a Malvern Zetasizer Nano ZS instrument (Malvern Instrument, UK). The prepared CNP samples were centrifuged at 13,000 rpm for $20 \mathrm{~min}$ and diluted in $\mathrm{sdH}_{2} \mathrm{O}$ at $60: 40\left(\mathrm{sdH}_{2} \mathrm{O}: \mathrm{CNP}\right)$ ratio before analyzing them using DLS. The best $\mathrm{CNP}$ formulation (denoted hereon as $\mathrm{CNP}^{\circ}$ ) was used for the subsequent analysis.

3.5. Synthesis of Chitosan Nanoparticles-Encapsulated Chlorogenic Acid (CNP'-CGA) and Determination of Optimum Parameters for CNP ${ }^{\circ}-C G A$ Formation Using DLS and Encapsulation Efficiency Analyses

Chlorogenic acid (CGA) of $10 \mu \mathrm{M}, 50 \mu \mathrm{M}$, and $100 \mu \mathrm{M}$ initial concentration were prepared by dissolving the commercially purchased CGA powder in $\mathrm{sdH}_{2} \mathrm{O}$. The CGA was then mixed with the best $\mathrm{CNP}$ formulation; $\mathrm{CNP}^{\circ}$ to form $\mathrm{CNP}$ encapsulated CGA (CNP ${ }^{\circ}$-CGA). The particle size and PDI value of $\mathrm{CNP}^{\circ}$-CGA were analyzed via DLS method. While, to determine encapsulation efficiency (EE\%), the $\mathrm{CNP}^{\circ}$-CGA was prepared and centrifuged at 13,000 rpm, for $30 \mathrm{~min}$. The free, unloaded CGA were collected and the absorbance was measured at $A_{325}$ using spectrophotometer (Thermo Scientific Genesys 840-208100 UV/Vis Spectrophotometer). The percentage of encapsulation efficiency (EE, \%) and CGA loading (CGA-L, $\mu \mathrm{M}$ ) were calculated using the following formulas;

$$
\begin{gathered}
E E, \%=\frac{\text { Absorbance of total CGA }- \text { Absorbance of unloaded CGA }}{\text { Absorbance of total CGA }} \times 100 \% \\
\text { CGA }-\mathrm{L}, \mu \mathrm{M}=\mathrm{EE} \% \times \text { CGA concentration }
\end{gathered}
$$

The best $\mathrm{CNP}^{\circ}$-CGA parameter was then subsequently used in the following analyses.

\subsection{Morphological Assessment of $C N P^{\circ}$, and $C N P^{\circ}-C G A$ via Electron Microscopy}

To discern the formation hybrid nanoparticles, Field Emission Scanning Electron Microscopy (FESEM) and Transmission Electron Microscopy (TEM) were employed. The best parameter of CNP ${ }^{\circ}$ and $\mathrm{CNP}^{\circ}$-CGA were prepared as described earlier. The samples were placed on a stub and dried in incubator at $37^{\circ} \mathrm{C}$ for two to three days. The samples were then coated with gold and viewed under Ultra High Resolution FESEM (Nova NanoSEM 230, FEI). The CNP ${ }^{\circ}$ and $\mathrm{CNP}^{\circ}$-CGA images were then processed using ImageJ software to assess the particle size distribution. The size of $\mathrm{CNP}^{\circ}$ and $\mathrm{CNP}^{\circ}$-CGA particles were measured, and a histogram bar on diameter and normal distribution curve were plotted. While, for TEM analysis, both the samples were immobilized on copper grids and air dried before examining under TEM (Tecnai TF20×-Twin, FEI) at MIMOS Berhad. 


\subsection{Characterization of Functional Groups via Fourier-Transform-Infrared (FTIR) Spectroscopy}

FITR analysis was performed to study the molecular components and chemical functional groups present in a sample, in this case, $\mathrm{CS}, \mathrm{TPP}, \mathrm{CGA}, \mathrm{CNP}^{\circ}$, and $\mathrm{CNP}^{\circ}$-CGA. All samples were prepared fresh and were freeze dried before sending them for FTIR analysis at Faculty of Sciences, UPM. The obtained FTIR spectrum results were further analyzed.

\subsection{Evaluation of Free Radical Scavenging Activities of CGA Alone and CNP ${ }^{\circ}-C G A$}

The free radical scavenging activity of CGA, and CNP-CGA were evaluated using a modified DPPH radical scavenging assay protocol described previously by Blois, 1958 [124]. CNP ${ }^{\circ}$, CGA, $\mathrm{CNP}^{\circ}$-CGA, and ascorbic acid (standard) solutions were freshly prepared prior the analysis. Two-fold serial dilutions were then carried out for all the samples in distilled water. A hundred microliters of each sample dilution were mixed together with $100 \mu \mathrm{L}$ of $0.1 \mathrm{mM}$ DPPH in a 96-well plate. A hundred microliters of DPPH at $0.1 \mathrm{mM}$ was set as control. The samples were incubated at ambient temperature for $30 \mathrm{~min}$ in dark. The absorbance of the samples was read at the maximum absorbance of $\mathrm{A}_{517 \mathrm{~nm}}$ using a microplate reader (Bio-Tek Instrument, Winooski, VT, USA).

$$
\text { DPPH scavenging effect, } \%=\frac{\text { Absorbance of control }- \text { Absorbance of sample }}{\text { Absorbance of control }} \times 100 \%
$$

\subsection{Propagation and Maintenance of Human Renal Adenocarcinoma Cells, 786-O Cells}

Human renal adenocarcinoma cells, 786-O were obtained from ATCC (USA). The cell lines were grown and maintained in a complete growth media, CGM ( $90 \%$ of RPMI media; $10 \%$ of fetal bovine serum, FBS; and $1 \%$ of antibody). The adherent cells were incubated at $37^{\circ} \mathrm{C}$, and $5 \%$ of carbon dioxide $\left(\mathrm{CO}_{2}\right)$, and upon $80 \%$ to $100 \%$ confluency, the cells were used for subsequent cell treatment analysis or sub-cultured.

\subsection{MTT-Based Cytotoxicity Analyses of $C G A, C N P^{\circ}$, and $C N P^{\circ}-C G A$}

MTT assay was used to measure the cytotoxicity of the CGA, CNP ${ }^{\circ}$, and CNP ${ }^{\circ}$-CGA on 786-O cells. The 786-O cells were seeded on a 96 well plate at a volume of $100 \mu \mathrm{L}$, and a density of $10 \times 10^{3}$ cells/per well. The cells were incubated at $37^{\circ} \mathrm{C}$ for overnight. The next day, the CGM from each well was discarded and replaced with $100 \mu \mathrm{L}$ of fresh CGM. Freshly prepared $\mathrm{CNP}^{\circ}, \mathrm{CGA}$, and $\mathrm{CNP}^{\circ}$-CGA samples were diluted (two-fold dilution) in CGM and a $100 \mu \mathrm{L}$ of each diluted samples were mixed into each well and the plate was left to incubate at $37^{\circ} \mathrm{C}, 5 \% \mathrm{CO}_{2}$ for $24 \mathrm{~h}$. The untreated well was used as control, and well with media only was used as blank. After $24 \mathrm{~h}$, the samples were discarded, and replaced with $170 \mu \mathrm{L}$ of fresh CGM, and $30 \mu \mathrm{L}$ MTT ( $5 \mathrm{mg} / \mathrm{mL}$ in $1 \times$ PBS). The plate was covered with aluminium foil and incubated for $4 \mathrm{~h}$ at $37^{\circ} \mathrm{C}$. Subsequently, $150 \mu \mathrm{L}$ of the solution from each well was discarded prior to addition of $100 \mu \mathrm{L}$ of DMSO to solubilize the formazan crystals. The absorbance was immediately read at $A_{570 \mathrm{~nm}}$ using a microplate reader. The percentage of cell viability was calculated using the following formula;

$$
\text { Cell viability, } \%=\frac{\text { Absorbance of control }- \text { Absorbance of sample }}{\text { Absorbance of control }} \times 100 \%
$$

\subsection{Fluorescent Labeling of Chitosan Nanoparticles-Encapsulated Chlorogenic Acid, fCNP ${ }^{\circ}-C G A$}

The primary amine groups of CS were covalently conjugated to $0.25 \mathrm{mg} / \mathrm{mL}$ of fluorescein isothiocyanate (FITC), which was dissolved in DMSO. The solution was incubated for $15 \mathrm{~min}$. Successively, CGA, and TPP were added into the solution. Formed $f C N \mathrm{CP}^{\circ}$-CGA was used in the following analyses. 


\subsection{In Vitro Visualization and Quantification of $f C N P^{\circ}-C G A$ in $786-O$ Cancer Cells}

Human renal adenocarcinoma cells, 786-O were seeded on 6 well plate at a density of $1 \times 10^{5}$ cells/per well, and incubated for $24 \mathrm{~h}$ at $37{ }^{\circ} \mathrm{C}$ and $5 \%$ of $\mathrm{CO}_{2}$. The following day, the CGM was removed; the cells were rinsed with 1x Phosphate Buffered Saline (PBS), and fresh CGM were added into the wells. The cells were treated with FITC only for $48 \mathrm{~h}$, and $f C \mathrm{NP}^{\circ}$-CGA in dark at different time points; for $30 \mathrm{~min}, 6 \mathrm{~h}, 24 \mathrm{~h}$, and $48 \mathrm{~h}$. The non-treated cells were used as control. The plate was covered with aluminium foil to avoid light exposure. After each time point, the samples were removed from the wells, rinsed with $1 \times$ PBS, and $2 \mathrm{~mL}$ of fresh CGM was added into each well. The cells were observed under fluorescent microscope, while for flow cytometry analysis, after each time point, the samples were discarded from the wells, rinsed with $1 \times$ PBS, and trypsinized. Upon trypsinization, the cells from each well were collected into individual tubes, centrifuged at $1000 \mathrm{rpm}$ for $5 \mathrm{~min}$. The pellets obtained were suspended in $1 \mathrm{~mL}$ of MASC buffer ( $2 \% \mathrm{FBS}, 80 \% 1 \times \mathrm{PBS}$, and EDTA at pH 8 ) before analyzing in a NovoCyte flow cytometry (ACEA Biosciences, Inc., San Diego, CA, USA).

\subsection{Statistical Data Analysis}

Triplicate independent reads were measured for all the analyses, and expressed as mean $(n=3) \pm$ standard deviation (SD). The statistical significant of data was evaluated using Dunnett's multiple comparison test, One Way Analysis of Variance (ANOVA), GraphPad Prism; at probability value less than $0.05(P<0.05)$, with degree of significant denoted with asterisk $\left(^{*}\right)$ symbol on.

\section{Conclusions}

Formation of stable, monodispersed, chitosan nanoparticle was achieved through spontaneous ionic gelation between cationic CS and anionic TPP. Nanoparticles obtained were under $100 \mathrm{~nm}$ in size, and TPP volume was found to greatly influenced formation of CNP across different formulations; CNP-F1 (0.5 mg/mL CS and $0.7 \mathrm{mg} / \mathrm{mL}$ TPP), CNP-F2 $(0.25 \mathrm{mg} / \mathrm{mL} \mathrm{CS}$ and $0.35 \mathrm{mg} / \mathrm{mL}$ TPP), and CNP-F3 $\left(0.1 \mathrm{mg} / \mathrm{mL}\right.$ CS and $0.2 \mathrm{mg} / \mathrm{mL}$ TPP). At lower TPP volumes, inadequate $-\mathrm{PO}_{4}{ }^{3-}$ were available to form ionic cross-linking with $-\mathrm{NH}_{3}{ }^{+}$, hence, formation of large sized and unstable particles. Inversely, at higher TPP volumes, stable and monodispersed nanoparticles were formed due to increasing availability of $-\mathrm{PO}_{4}{ }^{3-}$ to form ionic interactions with CS. The most reproducible, stable and monodispersed $\mathrm{CNP}^{\circ}$ formulation was obtained at optimal parameters consist of $600 \mu \mathrm{L} \mathrm{CS}$ $(0.5 \mathrm{mg} / \mathrm{mL})$ at $\mathrm{pH} 5$ and $200 \mu \mathrm{L} \mathrm{TPP}(0.7 \mathrm{mg} / \mathrm{mL})$ at $\mathrm{pH} 2$; with an average particle size of $80.89 \pm 5.16$ $\mathrm{nm}$ and a polydispersity index (PDI) of $0.26 \pm 0.01$.

Encapsulation of the phytochemical CGA into $\mathrm{CNP}^{\circ}$ was initiated through electrostatic interactions between CGA and protonated $-\mathrm{NH}_{3}{ }^{+}$of CS. The optimal parameter in synthesizing CGA loaded CNP ${ }^{\circ}$ was attained at $200 \mu \mathrm{L}$ of $100 \mu \mathrm{M}$ CGA (initial concentration), $600 \mu \mathrm{L}$ of $0.5 \mathrm{mg} / \mathrm{mL} \mathrm{CS}$, and $200 \mu \mathrm{L}$ of $0.7 \mathrm{mg} / \mathrm{mL}$ TPP. CNP $^{\circ}$-CGA formation using $100 \mu \mathrm{M}$ CGA led to a prominent increase in $\mathrm{CNP}^{\circ}$ particle size (an increase of $66.20 \%$ ) with a conserved particle stability and monodispersity (PDI $0.29 \pm 0.03$ ) as compared to encapsulation of $10 \mu \mathrm{M}$ (an increase of $13.72 \%$ ) and $50 \mu \mathrm{M}$ (an increase of $2.11 \%$ ). The significant CGA-L, $\mu \mathrm{M}$ at this optimal parameter was recorded as the highest, $12.04 \mu \mathrm{M}$, despite the lowest CGA-EE $\%, 60.21 \pm 0.03 \%$ compared to the other two concentrations.

The DPPH scavenging efficacy of $\mathrm{CNP}^{\circ}$-CGA $\left(\mathrm{IC}_{50}: 5 \mu \mathrm{M}\right)$ was slightly better compared to CGA alone $\left(\mathrm{IC}_{50}: 6.5 \mu \mathrm{M}\right)$, and was able to scavenge the same amount of free radicals at lower CGA concentrations compared to CGA. Apart from that, both $\mathrm{CNP}^{\circ}$ and CGA showed non-toxic properties towards human renal adenocarcinoma, 786-O cells, with percentage of cell viability of $81.37 \pm 0.84 \%$ and above $100 \%$, respectively. Inversely, $\mathrm{CNP}^{\circ}$-CGA prompted a better cytotoxic efficacy by reducing cell viability to $60.22 \%$ (at $12 \mu \mathrm{M}$ ) after $24 \mathrm{~h}$ post-treatment. In addition, the in vitro cellular (human renal adenocarcinoma 786-O cells) accumulation study disclosed that cellular internalization of fluorescently labeled $\mathrm{CNP}^{\circ}$-CGA begun as early as $30 \mathrm{~min}$ and proceeded up to $48 \mathrm{~h}$ post-treatment. Inferring, the cationic feature of $\mathrm{CNP}^{\circ}$ shell secured and facilitated the uptake of CGA across the cell membrane. 
The synthesized $\mathrm{CNP}^{\circ}$ vector is a good drug delivery system (DDS) candidate for CGA cargo by increasing its in vitro accumulation, thus, improving the bioavailability of CGA and enhancing its antioxidant and cytotoxic properties; hence, potentially lowers the administrative CGA dosages. Furthermore, positive surface charge of $\mathrm{CNP}^{\circ}$ benefited as DDS by accommodating negatively charged drugs, by providing protective shell for the payload, and facilitating the permeability of encapsulated payload across the cellular membrane.

Hitherto, researchers have been widely adapting CNP as a safe option for DDS, and CGA as a therapeutic compound in pharmaceutical industries. $\mathrm{CNP}^{\circ}$ vector plays an importance role in delivering CGA across the membrane, which in turn influences the cellular uptake of CGA, increases its bioavailability, conserves its therapeutic efficacy, and reduces possible occurrence of side effects by reducing the administration dosage of CGA. Nevertheless, the molecular level mechanisms of CGA therapeutic efficacy and $\mathrm{CNP}$ as vector, stability of $\mathrm{CNP}^{\circ}$-CGA, release kinetics of $\mathrm{CNP}^{\circ}$-CGA, and antioxidant activity, in both in vitro and in vivo studies have yet to be explored further. These in-depth studies are crucial to the design of an efficient chitosan nanoparticle mediated delivery system that could potential protect and enhance the therapeutic efficacy of CGA as a treatment for chronic disease, specifically cancer.

Supplementary Materials: Supplementary materials can be found at http://www.mdpi.com/1422-0067/20/19/ 4667/s1.

Author Contributions: M.Z.H., S.F., and M.J.M. were involved in conceptualization of the project and acquisition of the funding. R.K.R. and M.J.M. comprehended, designed the methodology, validated, analyzed the data, and curated the data. R.K.R. carried out the experiments, visualized, and wrote the paper. M.J.M. administrated and supervised the project. M.Z.H., S.F., M.J.M., and K.Y. provided analytical resources such as materials, reagents, equipment, and laboratory space to accomplish the experiments. R.K.R., M.J.M., M.Z.H., S.F., and K.Y. reviewed and edited the paper.

Funding: This research received funding from Universiti Putra Malaysia under the Geran Inisiatif Putra Berkumpulan (GP-IPB) under project VOT 9425801.

Acknowledgments: Revathi Kavi Rajan and Mas Jaffri Masarudin would like to thank UPM for funding the research under the Geran Inisiatif Putra Berkumpulan grant VOT 9425801. Revathi Kavi Rajan would like to acknowledge two bodies that have funded her postgraduate study; Universiti Putra Malaysia (UPM) for provisions of a Graduate Research Fellow (GRF) and the Ministry of Education, Malaysia for the myBrain15 scholarship scheme. Revathi Kavi Rajan also acknowledges the Institute of Advanced Technology (UPM), Faculty of Science (UPM, Agro-Biotechnology Institute Malaysia (ABI), Animal Tissue Culture Lab (UPM), Institute of Bioscience (UPM), and MIMOS Berhad for the permission to utilize their laboratory facilities to accomplish the research. Revathi Kavi Rajan also would like to extend her heart felt gratitude to her parents, lab mates, and friends who have supported and helped her throughout the postgraduate journey.

Conflicts of Interest: The authors declare no conflict of interest.

\section{Abbreviations}

\begin{tabular}{|c|c|}
\hline$\mu \mathrm{L}$ & Microliter \\
\hline$\mu \mathrm{M}$ & Micromolar \\
\hline 5-CQA & 5-O-caffeoylquinic acid \\
\hline $786-\mathrm{O}$ & Human renal cancer cell line \\
\hline ANOVA & One Way Analysis of Variance \\
\hline ARE & Antioxidant response element \\
\hline${ }^{\circ} \mathrm{C}$ & Degree Celsius \\
\hline CGA & Chlorogenic acid \\
\hline CGA-EE\% & CGA encapsulation efficacy \\
\hline CGA-L & CGA loading \\
\hline CGM & Complete growth media \\
\hline $\mathrm{cm}$ & Centimeter \\
\hline CNP & Chitosan nanoparticles \\
\hline $\mathrm{CNP}^{\circ}$ & Chitosan nanoparticles at optimum parameter \\
\hline $\mathrm{CNP}^{\circ}$-CGA & Chitosan nanoparticles-encapsulated chlorogenic acid at optimal parameter \\
\hline CNP-F1 & Chitosan nanoparticle-Formulation 1 \\
\hline
\end{tabular}




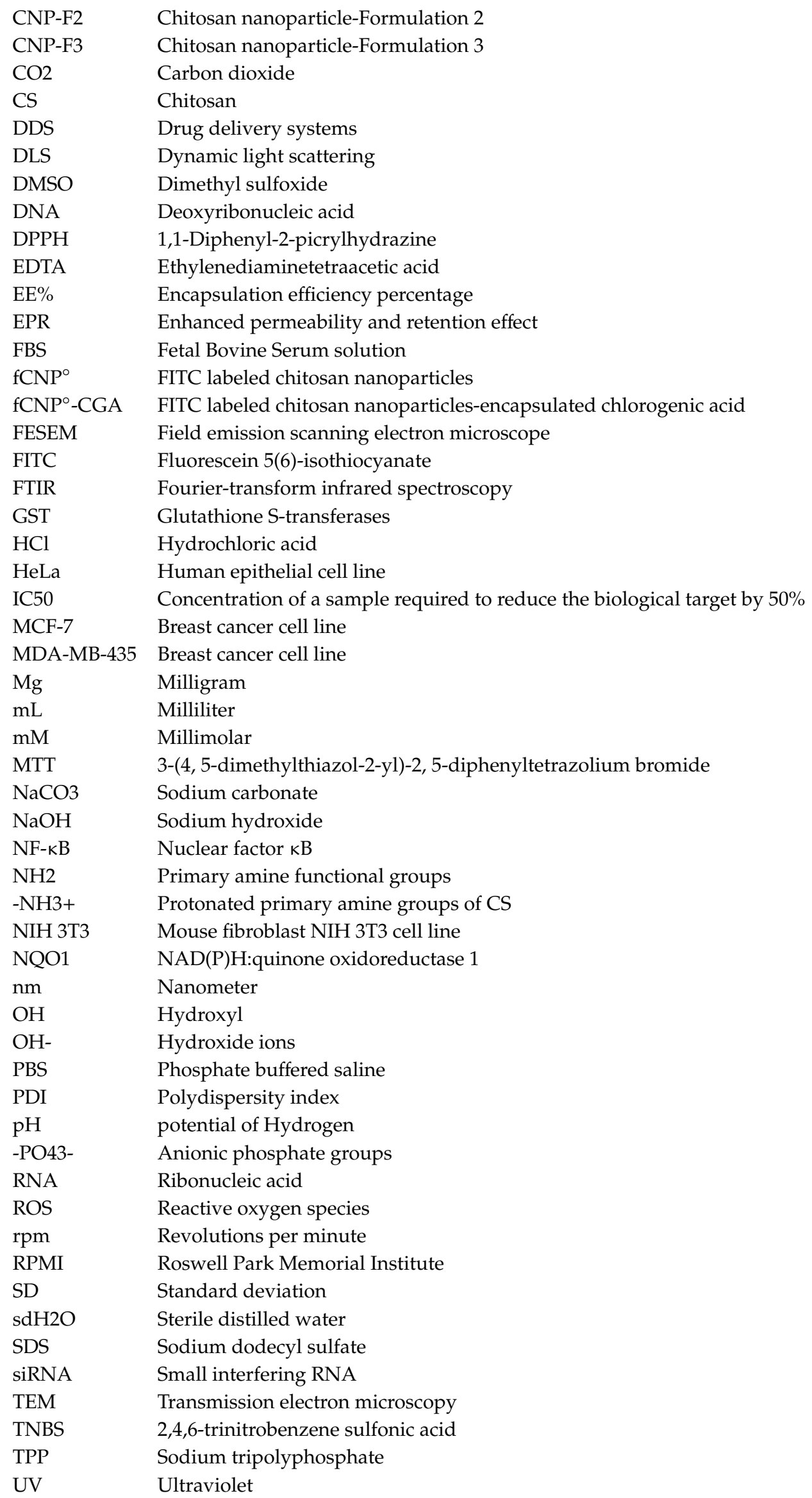




\section{References}

1. Farah, A.; Monteiro, M.; Donangelo, C.M.; Lafay, S. Chlorogenic acids from green coffee extract are highly bioavailable in humans. J. Nutr. 2008, 138, 2309-2315. [CrossRef] [PubMed]

2. Sato, Y.; Itagaki, S.; Kurokawa, T.; Ogura, J.; Kobayashi, M.; Hirano, T.; Sugawara, M.; Iseki, K. In vitro and in vivo antioxidant properties of chlorogenic acid and caffeic acid. Int. J. Pharm. 2011, 403, 136-138. [CrossRef] [PubMed]

3. Yan, K.; Cui, M.; Zhao, S.; Chen, X.; Tang, X. Salinity stress is beneficial to the accumulation of chlorogenic acids in honeysuckle (Lonicera japonica Thunb.). Front. Plant. Sci. 2016, 7, 1563. [CrossRef] [PubMed]

4. Clifford, M.N. Chlorogenic acids and other cinnamates-nature, occurrence and dietary burden. J. Sci. Food Agric. 1999, 79, 362-372. [CrossRef]

5. Clifford, M.N. Chlorogenic acids and other cinnamates-nature, occurrence, dietary burden, absorption and metabolism. J. Sci. Food Agric. 2000, 80, 1033-1043. [CrossRef]

6. Niggeweg, R.; Michael, A.J.; Martin, C. Engineering plants with increased levels of the antioxidant chlorogenic acid. Nat. Biotechnol. 2004, 22, 746-754. [CrossRef] [PubMed]

7. Farah, A.; Donangelo, C.M. Phenolic compounds in coffee. Braz. J. Plant. Physiol. 2006, 18, 23-36. [CrossRef]

8. Nallamuthu, I.; Devi, A.; Khanum, F. Chlorogenic acid loaded chitosan nanoparticles with sustained release property, retained antioxidant activity and enhanced bioavailability. Asian J. Pharm. Sci. 2015, 10, $203-211$. [CrossRef]

9. Rice-Evans, C.A.; Miller, N.J.; Paganga, G. Structure-antioxidant activity relationships of flavonoids and phenolic acids. Free Radic. Biol. Med. 1996, 20, 933-956. [CrossRef]

10. Kono, Y.; Kobayashi, K.; Tagawa, S.; Adachi, A.; Ueda, A.; Sawa, Y.; Shibata, H. Antioxidant activity of polyphenolics in diets: Rate constants of reactions of chlorogenic acid and caffeic acid with reactive species of oxygen and nitrogen. Biochim. Et Biophys. Acta 1997, 1335, 335-342. [CrossRef]

11. Kono, Y.; Shibata, H.; Kodama, Y.; Sawa, Y. The suppression of the N-nitrosating reaction by chlorogenic acid. Biochem. J. 1995, 312, 947-953. [CrossRef] [PubMed]

12. Zhang, L.Y.; Cosma, G.; Gardner, H.; Vallyathan, V.; Castranova, V. Effect of chlorogenic acid on hydroxyl radical. Mol. Cell. Biochem. 2003, 247, 205-210. [CrossRef] [PubMed]

13. Santana-Gálvez, J.; Cisneros-Zevallos, L.; Jacobo-Velázquez, D.A. Chlorogenic acid: Recent advances on its dual role as a food additive and a nutraceutical against metabolic syndrome. Molecules 2017, $22,358$. [CrossRef] [PubMed]

14. Lu, Y.; Foo, L.Y. Antioxidant and radical scavenging activities of polyphenols from apple pomace. Food Chem. 2000, 68, 81-85. [CrossRef]

15. Wang, G.F.; Shi, L.P.; Ren, Y.D.; Liu, Q.F.; Liu, H.F.; Zhang, R.J.; Tao, P.Z. Anti-hepatitis B virus activity of chlorogenic acid, quinic acid and caffeic acid in vivo and in vitro. Antivir. Res. 2009, 83, 186-190. [CrossRef] [PubMed]

16. Sung, W.S.; Lee, D.G. Antifungal action of chlorogenic acid against pathogenic fungi, mediated by membrane disruption. Pure Appl. Chem. 2010, 82, 219-226. [CrossRef]

17. Lou, Z.; Wang, H.; Zhu, S.; Ma, C.; Wang, Z. Antibacterial activity and mechanism of action of chlorogenic acid. J. Food Sci. 2011, 76, M398-M403. [CrossRef]

18. Cho, A.S.; Jeon, S.M.; Kim, M.J.; Yeo, J.; Seo, K.; Choi, M.S.; Lee, M.K. Chlorogenic acid exhibits anti-obesity property and improves lipid metabolism in high-fat diet-induced-obese mice. Food Chem. Toxicol. 2010, 48, 937-943. [CrossRef]

19. Kasai, H.; Fukada, S.; Yamaizumi, Z.; Sugie, S.; Mori, H. Action of chlorogenic acid in vegetables and fruits as an inhibitor of 8-hydroxydeoxyguanosine formation in vitro and in a rat carcinogenesis model. Food Chem. Toxicol. 2000, 38, 467-471. [CrossRef]

20. Zhao, Y.; Wang, J.; Ballevre, O.; Luo, H.; Zhang, W. Antihypertensive effects and mechanisms of chlorogenic acids. Hypertens. Res. 2012, 35, 370-374. [CrossRef]

21. Meng, S.; Cao, J.; Feng, Q.; Peng, J.; Hu, Y. Roles of chlorogenic acid on regulating glucose and lipids metabolism: A review. Evid. Based Complement. Alternat. Med. 2013, 2013, 801457. [CrossRef] [PubMed]

22. Li, Y.; Shen, D.; Tang, X.; Li, X.; Wo, D.; Yan, H.; Li, J. Chlorogenic acid prevents isoproterenol-induced hypertrophy in neonatal rat myocytes. Toxicol. Lett. 2014, 226, 257-263. [CrossRef] [PubMed] 
23. De Maria, C.A.B.; Trugo, L.C.; e Miranda, L.D.M.; Salvador, E. Stability of 5-caffeoylquinic acid under different conditions of heating. Food Res. Int. 1998, 31, 475-477. [CrossRef]

24. Friedman, M.; Jürgens, H.S. Effect of $\mathrm{pH}$ on the stability of plant phenolic compounds. J. Agric. Food Chem. 2000, 48, 2101-2110. [CrossRef] [PubMed]

25. Zanoelo, E.F.; Beninca, C. Chemical kinetics of 5-o-caffeoylquinic acid in superheated steam: Effect of isomerization on mate (Ilex paraguariensis) manufacturing. J. Agric. Food Chem. 2009, 57, 11564-11569. [CrossRef] [PubMed]

26. Dawidowicz, A.L.; Wianowska, D.; Olszowy, M. On practical problems in estimation of antioxidant activity of compounds by DPPH method (Problems in estimation of antioxidant activity). Food Chem. 2012, 131, 1037-1043. [CrossRef]

27. Ma, Z.; Lim, L.Y. Uptake of chitosan and associated insulin in Caco-2 cell monolayers: A comparison between chitosan molecules and chitosan nanoparticles. Pharm. Res. 2003, 20, 1812-1819. [CrossRef]

28. Olthof, M.R.; Hollman, P.C.H.; Katan, M.B. Chlorogenic acid and caffeic acid are absorbed in humans. J. Nutr. 2001, 131, 66-71. [CrossRef] [PubMed]

29. Gonthier, M.P.; Verny, M.A.; Besson, C.; Rémésy, C.; Scalbert, A. Chlorogenic acid bioavailability largely depends on its metabolism by the gut microflora in rats. J. Nutr. 2003, 133, 1853-1859. [CrossRef]

30. Dupas, C.; Marsset Baglieri, A.; Ordonaud, C.; Tomé, D.; Maillard, M.N. Chlorogenic acid is poorly absorbed, independently of the food matrix: A Caco-2 cells and rat chronic absorption study. Mol. Nutr. Food Res. 2006, 50, 1053-1060. [CrossRef]

31. Barahuie, F.; Hussein, M.Z.; Arulselvan, P.; Fakurazi, S.; Zainal, Z. Drug delivery system for an anticancer agent, chlorogenate-Zn/Al-layered double hydroxide nanohybrid synthesized using direct co-precipitation and ion exchange methods. J. Solid State Chem. 2014, 217, 31-41. [CrossRef]

32. Burgos-Morón, E.; Calderón-Montaño, J.M.; Orta, M.L.; Pastor, N.; Pérez-Guerrero, C.; Austin, C.; López-Lázaro, M. The coffee constituent chlorogenic acid induces cellular DNA damage and formation of topoisomerase I-and II-DNA complexes in cells. J. Agric. Food Chem. 2012, 60, 7384-7391. [CrossRef] [PubMed]

33. Olthof, M.R.; Hollman, P.C.; Zock, P.L.; Katan, M.B. Consumption of high doses of chlorogenic acid, present in coffee, or of black tea increases plasma total homocysteine concentrations in humans. Am. J. Clin. Nutr. 2001, 73, 532-538. [CrossRef] [PubMed]

34. Du, W.Y.; Chang, C.; Zhang, Y.; Liu, Y.Y.; Sun, K.; Wang, C.S.; Wang, M.X.; Liu, Y.; Wang, F.; Fan, J.Y.; et al. High-dose chlorogenic acid induces inflammation reactions and oxidative stress injury in rats without implication of mast cell degranulation. J. Ethnopharmacol. 2013, 147, 74-83. [CrossRef] [PubMed]

35. Barahuie, F.; Hussein, M.Z.; Arulselvan, P.; Fakurazi, S.; Zainal, Z. Controlled in vitro release of the anticancer drug chlorogenic acid using magnesium/aluminium-layered double hydroxide as a nanomatrix. Sci. Adv. Mater. 2016, 8, 501-513. [CrossRef]

36. Gouthamchandra, K.; Sudeep, H.V.; Venkatesh, B.J.; Prasad, K.S. Chlorogenic acid complex (CGA7), standardized extract from green coffee beans exerts anticancer effects against cultured human colon cancer HCT-116 cells. Food Sci. Hum. Wellness 2017, 6, 147-153. [CrossRef]

37. Shi, G.; Rao, L.; Yu, H.; Xiang, H.; Pen, G.; Long, S.; Yang, C. Yeast-cell-based microencapsulation of chlorogenic acid as a water-soluble antioxidant. J. Food Eng. 2007, 80, 1060-1067. [CrossRef]

38. Naso, L.G.; Valcarcel, M.; Roura-Ferrer, M.; Kortazar, D.; Salado, C.; Lezama, L.; Ferrer, E.G. Promising antioxidant and anticancer (human breast cancer) oxidovanadium (IV) complex of chlorogenic acid. Synthesis, characterization and spectroscopic examination on the transport mechanism with bovine serum albumin. J. Inorg. Biochem. 2014, 135, 86-99. [CrossRef]

39. Barahuie, F.; Saifullah, B.; Dorniani, D.; Fakurazi, S.; Karthivashan, G.; Hussein, M.Z.; Elfghi, F.M. Graphene oxide as a nanocarrier for controlled release and targeted delivery of an anticancer active agent, chlorogenic acid. Mater. Sci. Eng. Cmaterials Biol. Appl. 2017, 74, 177-185. [CrossRef]

40. Agnihotri, S.A.; Mallikarjuna, N.N.; Aminabhavi, T.M. Recent advances on chitosan-based micro-and nanoparticles in drug delivery. J. Control. Release 2004, 100, 5-28. [CrossRef]

41. Shapi_i, R.A.; Othman, S.H.; Nazli Naim, M.; Kadir Basha, R. Effect of ball milling and ultrasonication time on particle size of chitosan for potential nanofiller in food packaging film. Acta Hortic 2017, 1152, 125-130. [CrossRef] 
42. Mohanraj, V.J.; Chen, Y.; Suresh, B. Chitosan-based nanoparticles for delivery of proteins and peptides. Indian J. Pharm. Educ. Res. 2006, 40, 106.

43. Szymańska, E.; Winnicka, K. Stability of chitosan-A challenge for pharmaceutical and biomedical applications. Mar. Drugs 2015, 13, 1819-1846. [CrossRef] [PubMed]

44. Ahmed, S.; Ahmad, M.; Swami, B.L.; Ikram, S. A review on plants extract mediated synthesis of silver nanoparticles for antimicrobial applications: A green expertise. J. Adv. Res. 2016, 7, 17-28. [CrossRef] [PubMed]

45. Larsen, A.K.; Escargueil, A.E.; Skladanowski, A. Resistance mechanisms associated with altered intracellular distribution of anticancer agents. Pharmacol. Ther. 2000, 85, 217-229. [CrossRef]

46. Panyam, J.; Dali, M.M.; Sahoo, S.K.; Ma, W.; Chakravarthi, S.S.; Amidon, G.L.; Levy, R.J.; Labhasetwar, V. Polymer degradation and in vitro release of a model protein from poly(D,L-lactide-co-glycolide) nano-and microparticles. J. Control. Release 2003, 92, 173-187. [CrossRef]

47. Cho, K.; Wang, X.U.; Nie, S.; Shin, D.M. Therapeutic nanoparticles for drug delivery in cancer. Clin. Cancer Res. 2008, 14, 1310-1316. [CrossRef]

48. Zhang, L.; Gu, F.X.; Chan, J.M.; Wang, A.Z.; Langer, R.S.; Farokhzad, O.C. Nanoparticles in medicine: Therapeutic applications and developments. Clin. Pharmacol. Ther. 2008, 83, 761-769. [CrossRef]

49. Wicki, A.; Witzigmann, D.; Balasubramanian, V.; Huwyler, J. Nanomedicine in cancer therapy: Challenges, opportunities, and clinical applications. J. Control. Release 2015, 200, 138-157. [CrossRef]

50. Vila, A.; Sánchez, A.; Janes, K.; Behrens, I.; Kissel, T.; Jato, J.L.V.; Alonso, M.J. Low molecular weight chitosan nanoparticles as new carriers for nasal vaccine delivery in mice. Eur. J. Pharm. Biopharm. 2004, 57, 123-131. [CrossRef]

51. Sannan, T.; Kurita, K.; Iwakura, Y. Studies on chitin, 2. Effect of deacetylation on solubility. Macromol. Chem. Phys. 1976, 177, 3589-3600. [CrossRef]

52. Masarudin, M.J.; Cutts, S.M.; Evison, B.J.; Phillips, D.R.; Pigram, P.J. Factors determining the stability, size distribution, and cellular accumulation of small, monodisperse chitosan nanoparticles as candidate vectors for anticancer drug delivery: Application to the passive encapsulation of $\left[{ }^{14} \mathrm{C}\right]$-doxorubicin. Nanotechnol. Sci. Appl. J. 2015, 8, 67-80. [CrossRef] [PubMed]

53. Desai, M.P.; Labhasetwar, V.; Amidon, G.L.; Levy, R.J. Gastrointestinal uptake of biodegradable microparticles: Effect of particle size. Pharm. Res. 1996, 13, 1838-1845. [CrossRef] [PubMed]

54. Barua, S.; Mitragotri, S. Challenges associated with penetration of nanoparticles across cell and tissue barriers: A review of current status and future prospects. Nano Today 2014, 9, 223-243. [CrossRef] [PubMed]

55. Blanco, E.; Shen, H.; Ferrari, M. Principles of nanoparticle design for overcoming biological barriers to drug delivery. Nat. Biotechnol. 2015, 33, 941-951. [CrossRef] [PubMed]

56. Braun, G.B.; Friman, T.; Pang, H.B.; Pallaoro, A.; De Mendoza, T.H.; Willmore, A.M.A.; Reich, N.O. Etchable plasmonic nanoparticle probes to image and quantify cellular internalization. Nat. Mater. 2014, $13,904$. [CrossRef] [PubMed]

57. Fan, W.; Yan, W.; Xu, Z.; Ni, H. Formation mechanism of monodisperse, low molecular weight chitosan nanoparticles by ionic gelation technique. Colloids Surf. B Biointerfaces 2012, 90, 21-27. [CrossRef]

58. Udaybhaskar, P.; Iyengar, L.; Rao, A.V.S. Hexavalent chromium interaction with chitosan. J. Appl. Polym. Sci. 1990, 39, 739-747. [CrossRef]

59. Ramanery, F.P.; Mansur, A.A.; Mansur, H.S. One-step colloidal synthesis of biocompatible water-soluble ZnS quantum dot/chitosan nanoconjugates. Nanoscale Res. Lett. 2013, 8, 512. [CrossRef]

60. Xiao, Z.; Tian, T.; Hu, J.; Wang, M.; Zhou, R. Preparation and characterization of chitosan nanoparticles as the delivery system for tuberose fragrance. Flavour Fragr. J. 2014, 29, 22-34. [CrossRef]

61. Tsai, M.L.; Chen, R.H.; Bai, S.W.; Chen, W.Y. The storage stability of chitosan/tripolyphosphate nanoparticles in a phosphate buffer. Carbohydr. Polym. 2011, 84, 756-761. [CrossRef]

62. Bhumkar, D.R.; Pokharkar, V.B. Studies on effect of $\mathrm{pH}$ on cross-linking of chitosan with sodium tripolyphosphate: A technical note. Aaps Pharmascitech 2006, 7, E138-E143. [CrossRef] [PubMed]

63. Ko, J.A.; Park, H.J.; Hwang, S.J.; Park, J.B.; Lee, J.S. Preparation and characterization of chitosan microparticles intended for controlled drug delivery. Int. J. Pharm. 2002, 249, 165-174. [CrossRef]

64. Villegas, R.J.A.; Shimokawa, T.; Okuyama, H.; Kojima, M. Purification and characterization of chlorogenic acid: Chlorogenate caffeoyl transferase in sweet potato roots. Phytochemistry 1987, 26, 1577-1581. [CrossRef] 
65. Oliver, S.; Vittorio, O.; Cirillo, G.; Boyer, C. Enhancing the therapeutic effects of polyphenols with macromolecules. Polym. Chem. 2016, 7, 1529-1544. [CrossRef]

66. Liu, D.; Mori, A.; Huang, L. Role of liposome size and RES blockade in controlling biodistribution and tumor uptake of GM1-containing liposomes. Biochim. Et Biophys. Acta (Bba)-Biomembr. 1992, 1104, 95-101. [CrossRef]

67. He, C.; Hu, Y.; Yin, L.; Tang, C.; Yin, C. Effects of particle size and surface charge on cellular uptake and biodistribution of polymeric nanoparticles. Biomaterials 2010, 31, 3657-3666. [CrossRef] [PubMed]

68. Ernsting, M.J.; Murakami, M.; Roy, A.; Li, S.D. Factors controlling the pharmacokinetics, biodistribution and intratumoral penetration of nanoparticles. J. Control. Release 2013, 172, 782-794. [CrossRef] [PubMed]

69. Nagda, C.D.; Chotai, N.P.; Patel, S.B.; Soni, T.J.; Patel, U.L. Preparation and in vitro evaluation of bioadhesive microparticulate system. Int. J. Pharm. Sci. Nanotechnol. 2008, 1, 257-266.

70. Pavan Veena, C.; Kavitha, K.; Anil Kumar, S.N. Formulation and evaluation of Trimetazidine hydrochloride loaded chitosan microspheres. Int. J. Appl. Pharm. 2010, 2, 11-14.

71. Raja, M.A.G.; Katas, H.; Wen, T.J. Stability, intracellular delivery, and release of siRNA from chitosan nanoparticles using different cross-linkers. PLOS ONE 2015, 10, e0128963.

72. Pekarskaya, E.; Kim, C.P.; Johnson, W.L. In situ transmission electron microscopy studies of shear bands in a bulk metallic glass based composite. J. Mater. Res. 2001, 16, 2513-2518. [CrossRef]

73. Luo, Y.; Zhang, B.; Cheng, W.H.; Wang, Q. Preparation, characterization and evaluation of selenite-loaded chitosan/TPP nanoparticles with or without zein coating. Carbohydr. Polym. 2010, 82, 942-951. [CrossRef]

74. Chuah, L.H.; Billa, N.; Roberts, C.J.; Burley, J.C.; Manickam, S. Curcumin-containing chitosan nanoparticles as a potential mucoadhesive delivery system to the colon. Pharm. Dev. Technol. 2013, 18, 591-599. [CrossRef] [PubMed]

75. Ariff, S.A.Y.; Yusoff, K.; Masarudin, M.J. Encapsulation of miRNA in chitosan nanoparticles as a candidate for an anti-metastatic agent in cancer therapy. Malays. Appl. Biol. 2017, 46, 165-170.

76. Xu, Y.; Du, Y. Effect of molecular structure of chitosan on protein delivery properties of chitosan nanoparticles. Int. J. Pharm. 2003, 250, 215-226. [CrossRef]

77. Gierszewska-Drużyńska, M.; Ostrowska-Czubenko, J. The effect of ionic crosslinking on thermal properties of hydrogel chitosan membranes. Prog. Chem. Appl. Chitin Its Deriv. 2010, 16, 25-32.

78. Rodrigues, S.; da Costa, A.M.R.; Grenha, A. Chitosan/carrageenan nanoparticles: Effect of cross-linking with tripolyphosphate and charge ratios. Carbohydr. Polym. 2012, 89, 282-289. [CrossRef] [PubMed]

79. Catauro, M.; Barrino, F.; Dal Poggetto, G.; Pacifico, F.; Piccolella, S.; Pacifico, S. Chlorogenic acid/PEG-based organic-inorganic hybrids: A versatile sol-gel synthesis route for new bioactive materials. Mater. Sci. Eng. 2019, 100, 837-844. [CrossRef] [PubMed]

80. Gierszewska-Drużyńska, M.; Ostrowska-Czubenko, J. Influence of crosslinking process conditions on molecular and supermolecular structure of chitosan hydrogel membrane. Prog. Chem. Appl. Chitin Its Deriv. 2011, 15, 22.

81. Martins, A.F.; de Oliveira, D.M.; Pereira, A.G.; Rubira, A.F.; Muniz, E.C. Chitosan/TPP microparticles obtained by microemulsion method applied in controlled release of heparin. Int. J. Biol. Macromol. 2012, 51, 1127-1133. [CrossRef] [PubMed]

82. Aydin, R.; Pulat, M. 5-Fluorouracil encapsulated chitosan nanoparticles for pH-stimulated drug delivery: Evaluation of controlled release kinetics. J. Nanomater. 2012, 2012, 42.

83. Huang, Y.C.; Li, R.Y. Preparation and characterization of antioxidant nanoparticles composed of chitosan and fucoidan for antibiotics delivery. Mar. Drugs 2014, 12, 4379-4398. [CrossRef] [PubMed]

84. Allegretti, Y.; Ferrer, E.G.; Baró, A.G.; Williams, P.A.M. Oxovanadium (IV) complexes of quinic acid. Synthesis, characterization and potentiometric study. Polyhedron 2000, 19, 2613-2619. [CrossRef]

85. Cornard, J.P.; Lapouge, C. Theoretical and spectroscopic investigations of a complex of Al (III) with caffeic acid. J. Phys. Chem. A 2004, 108, 4470-4478. [CrossRef]

86. Biswas, N.; Kapoor, S.; Mahal, H.S.; Mukherjee, T. Adsorption of CGA on colloidal silver particles: DFT and SERS study. Chem. Phys. Lett. 2007, 444, 338-345. [CrossRef]

87. El-Abassy, R.M.; Donfack, P.; Materny, A. Discrimination between Arabica and Robusta green coffee using visible micro Raman spectroscopy and chemometric analysis. Food Chem. 2011, 126, 1443-1448. [CrossRef] 
88. Barahuie, F.; Hussein, M.Z.; Arulselvan, P.; Fakurazi, S.; Zainal, Z. Development of the anticancer potential of a chlorogenate-zinc layered hydroxide nanohybrid with controlled release property against various cancer cells. Sci. Adv. Mater. 2013, 5, 1983-1993. [CrossRef]

89. Leaves, L. Antioxidant activity by DPPH radical scavenging method of ageratum conyzoides. Am. J. Ethnomedicine. 2014, 1, 244-249.

90. Pisoschi, A.M.; Cheregi, M.C.; Danet, A.F. Total antioxidant capacity of some commercial fruit juice: Electrochemical and spectrophotometrical approaches. Molecule 2009, 14, 480-493. [CrossRef] [PubMed]

91. Medhe, S.; Bansal, P.; Srivastava, M.M. Enhanced antioxidant activity of gold nanoparticle embedded 3, 6-dihydroxyflavone: A combinational study. Appl. Nanosci. 2014, 4, 153-161. [CrossRef]

92. Valgimigli, L.; Amorati, R.; Fumo, M.G.; Dilabio, G.A.; Pedulli, G.F.; Ingold, K.U.; Pratt, D.A. The unusual reaction of semiquinone radicals with molecular oxygen. J. Org. Chem. 2008, 73, 1830-1841. [CrossRef] [PubMed]

93. Wheeler, S.E.; Houk, K.N. Substituent effects in the benzene dimer are due to direct interactions of the substituents with the unsubstituted benzene. J. Am. Chem. Soc. 2008, 130, 10854-10855. [CrossRef] [PubMed]

94. Wheeler, S.E.; Bloom, J.W. Towards a more complete understanding of noncovalent interactions involving aromatic rings. J. Phys. Chem. A 2014, 118, 6133-6147. [CrossRef] [PubMed]

95. Ramasamy, P.; Subhapradha, N.; Shanmugam, V.; Shanmugam, A. Extraction, characterization and antioxidant property of chitosan from cuttlebone Sepia kobiensis (Hoyle 1885). Int. J. Biol. Macromol. 2014, 64, $202-212$. [CrossRef] [PubMed]

96. Li, Q.; Zhang, C.; Tan, W.; Gu, G.; Guo, Z. Novel amino-pyridine functionalized chitosan quaternary ammonium derivatives: Design, synthesis, and antioxidant activity. Molecules 2017, 22, 156. [CrossRef] [PubMed]

97. Delie, F. Evaluation of nano-and microparticle uptake by the gastrointestinal tract. Adv. Drug Deliv. Rev. 1998, 34, 221-233. [CrossRef]

98. Orienti, K.; Aiedeh, E.; Gianasi, V.; Bertasi, V.; Zecchi. Indomethacin loaded chitosan microspheres. Correlation between the erosion process and release kinetics. J. Microencapsul. 1996, 13, 463-472. [CrossRef]

99. He, P.; Davis, S.S.; Illum, L. Chitosan microspheres prepared by spray drying. Int. J. Pharm. 1999, 187, 53-65. [CrossRef]

100. Pan, Y.; Li, Y.J.; Zhao, H.Y.; Zheng, J.M.; Xu, H.; Wei, G.; Hao, J.S. Bioadhesive polysaccharide in protein delivery system: Chitosan nanoparticles improve the intestinal absorption of insulin in vivo. Int. J. Pharm. 2002, 249, 139-147. [CrossRef]

101. Keawchaoon, L.; Yoksan, R. Preparation, characterization and in vitro release study of carvacrol-loaded chitosan nanoparticles. Colloids Surf. B Biointerfaces 2011, 84, 163-171. [CrossRef] [PubMed]

102. Hosseini, S.F.; Zandi, M.; Rezaei, M.; Farahmandghavi, F. Two-step method for encapsulation of oregano essential oil in chitosan nanoparticles: Preparation, characterization and in vitro release study. Carbohydr. Polym. 2013, 95, 50-56. [CrossRef] [PubMed]

103. Du, H.; Liu, M.; Yang, X.; Zhai, G. The design of $\mathrm{pH}$-sensitive chitosan-based formulations for gastrointestinal delivery. Drug Discov. Today 2015, 20, 1004-1011. [CrossRef] [PubMed]

104. Miladi, K.; Sfar, S.; Fessi, H.; Elaissari, A. Enhancement of alendronate encapsulation in chitosan nanoparticles. J. Drug Deliv. Sci. Technol. 2015, 30, 391-396. [CrossRef]

105. Scheeren, L.E.; Nogueira, D.R.; Macedo, L.B.; Vinardell, M.P.; Mitjans, M.; Infante, M.R.; Rolim, C.M. PEGylated and poloxamer-modified chitosan nanoparticles incorporating a lysine-based surfactant for pH-triggered doxorubicin release. Colloids Surf. B Biointerfaces 2016, 138, 117-127. [CrossRef] [PubMed]

106. Zhou, S.; Deng, X.; Li, X. Investigation on a novel core-coated microspheres protein delivery system. J. Control. Release 2001, 75, 27-36. [CrossRef]

107. Amidi, M.; Romeijn, S.G.; Borchard, G.; Junginger, H.E.; Hennink, W.E.; Jiskoot, W. Preparation and characterization of protein-loaded $\mathrm{N}$-trimethyl chitosan nanoparticles as nasal delivery system. J. Control. Release 2006, 111, 107-116. [CrossRef] [PubMed]

108. Hou, Y.; Hu, J.; Park, H.; Lee, M. Chitosan-based nanoparticles as a sustained protein release carrier for tissue engineering applications. J. Biomed. Mater. Res. Part. A 2012, 100, 939-947. [CrossRef] [PubMed]

109. Yang, H.; Xu, M.; Li, S.; Shen, X.; Li, T.; Yan, J.; Zhang, C.; Wu, C.; Zeng, H.; Liu, Y. Chitosan hybrid nanoparticles as a theranostic platform for targeted doxorubicin/VEGF shRNA co-delivery and dual-modality fluorescence imaging. RSC Adv. 2016, 6, 29685-29696. [CrossRef] 
110. Jia, X.; Chen, X.; Xu, Y.; Han, X.; Xu, Z. Tracing transport of chitosan nanoparticles and molecules in Caco-2 cells by fluorescent labeling. Carbohydr. Polym. 2009, 78, 323-329. [CrossRef]

111. Huang, M.; Ma, Z.; Khor, E.; Lim, L.Y. Uptake of FITC-chitosan nanoparticles by A549 cells. Pharm. Res. 2002, 19, 1488-1494. [CrossRef] [PubMed]

112. Sahay, G.; Alakhova, D.Y.; Kabanov, A.V. Endocytosis of nanomedicines. J. Control. Release 2010, 145, $182-195$. [CrossRef]

113. Zeng, X.; Morgenstern, R.; Nyström, A.M. Nanoparticle-directed sub-cellular localization of doxorubicin and the sensitization breast cancer cells by circumventing GST-mediated drug resistance. Biomaterials 2014, 35, 1227-1239. [CrossRef] [PubMed]

114. Liang, N.; Kitts, D.D. Role of chlorogenic acids in controlling oxidative and inflammatory stress conditions. Nutrients 2016, 8, 16. [CrossRef]

115. Kono, Y.; Shibata, H.; Kodama, Y.; Ueda, A.; Sawa, Y. Chlorogenic acid as a natural scavenger for hypochlorous acid. Biochem. Biophys. Res. Commun. 1995, 217, 972-978. [CrossRef] [PubMed]

116. Feng, R.; Lu, Y.; Bowman, L.L.; Qian, Y.; Castranova, V.; Ding, M. Inhibition of activator protein-1, NF- $k B$, and MAPKs and induction of phase 2 detoxifying enzyme activity by chlorogenic acid. J. Biol. Chem. 2005, 280, 27888-27895. [CrossRef]

117. Lee, W.J.; Zhu, B.T. Inhibition of DNA methylation by caffeic acid and chlorogenic acid, two common catechol-containing coffee polyphenols. Carcinogenesis 2005, 27, 269-277. [CrossRef]

118. Boettler, U.; Sommerfeld, K.; Volz, N.; Pahlke, G.; Teller, N.; Somoza, V.; Lang, R.; Hofmann, T.; Marko, D. Coffee constituents as modulators of Nrf2 nuclear translocation and ARE (EpRE)-dependent gene expression. J. Nutr. Biochem. 2011, 22, 426-440. [CrossRef]

119. Noratto, G.; Porter, W.; Byrne, D.; Cisneros-Zevallos, L. Identifying peach and plum polyphenols with chemopreventive potential against estrogen-independent breast cancer cells. J. Agric. Food Chem. 2009, 57, 5219-5226. [CrossRef]

120. Jin, U.H.; Lee, J.Y.; Kang, S.K.; Kim, J.K.; Park, W.H.; Kim, J.G.; Moon, S.K.; Kim, C.H. A phenolic compound, 5-caffeoylquinic acid (chlorogenic acid), is a new type and strong matrix metalloproteinase-9 inhibitor: Isolation and identification from methanol extract of Euonymus alatus. Life Sci. 2005, 77, 2760-2769. [CrossRef]

121. Dounighi, M.N.; Eskandari, R.; Avadi, M.R.; Zolfagharian, H.; Sadeghi, M.M.A.; Rezayat, M. Preparation and in vitro characterization of chitosan nanoparticles containing Mesobuthus eupeus scorpion venom as an antigen delivery system. J. Venom. Anim. Toxins Incl. Trop. Dis. 2012, 18, 44-52.

122. Saravanabhavan, S.S.; Bose, R.; Skylab, S.; Dharmalingam, S. Fabrication of chitosan/tpp nano particles as a carrier towards the treatment of cancer. Int. J. Drug Deliv. 2013, 5, 35.

123. Calvo, P.; Remuñan-Lopez, C.; Vila-Jato, J.L.; Alonso, M.J. Novel hydrophilic chitosanpolyethylene oxide nanoparticles as protein carriers. J. Appl. Polym. Sci. 1997, 63, 125-132. [CrossRef]

124. Blois, M.S. Antioxidant determinations by the use of a stable free radical. Nature 1958, 181, 1199-1200. [CrossRef]

(C) 2019 by the authors. Licensee MDPI, Basel, Switzerland. This article is an open access article distributed under the terms and conditions of the Creative Commons Attribution (CC BY) license (http://creativecommons.org/licenses/by/4.0/). 